\title{
Neurologic complications in small cell lung cancer
}

Citation for published version (APA):

Seute, T. (2008). Neurologic complications in small cell lung cancer. [Doctoral Thesis, Maastricht University]. Universiteit Maastricht. https://doi.org/10.26481/dis.20080201ts

Document status and date:

Published: 01/01/2008

DOI:

$10.26481 /$ dis.20080201ts

Document Version:

Publisher's PDF, also known as Version of record

\section{Please check the document version of this publication:}

- A submitted manuscript is the version of the article upon submission and before peer-review. There can be important differences between the submitted version and the official published version of record.

People interested in the research are advised to contact the author for the final version of the publication, or visit the DOI to the publisher's website.

- The final author version and the galley proof are versions of the publication after peer review.

- The final published version features the final layout of the paper including the volume, issue and page numbers.

Link to publication

\footnotetext{
General rights rights.

- You may freely distribute the URL identifying the publication in the public portal. please follow below link for the End User Agreement:

www.umlib.nl/taverne-license

Take down policy

If you believe that this document breaches copyright please contact us at:

repository@maastrichtuniversity.nl

providing details and we will investigate your claim.
}

Copyright and moral rights for the publications made accessible in the public portal are retained by the authors and/or other copyright owners and it is a condition of accessing publications that users recognise and abide by the legal requirements associated with these

- Users may download and print one copy of any publication from the public portal for the purpose of private study or research.

- You may not further distribute the material or use it for any profit-making activity or commercial gain

If the publication is distributed under the terms of Article $25 \mathrm{fa}$ of the Dutch Copyright Act, indicated by the "Taverne" license above, 
Neurologic complications in small cell lung cancer

Tatjana Seute 
The copyright of articles that have already been published or have been accepted for publication has been transferred to the respective journals.

Copyright: T. Seute, 2008

Lay out: Annemiek van der Kleijn, after the example of "Little by Little", Anton de Louw 2002 Printed by: Gildeprint drukkerijen BV

ISBN: 978-90-9022647-7 


\section{Neurologic complications in small cell lung cancer}

PROEFSCHRIFT

ter verkrijging van de graad van doctor aan de Universiteit Maastricht,

op gezag van de Rector Magnificus

Prof.mr. G.P.M.F. Mols

volgens het besluit van het College van Decanen

in het openbaar te verdedigen

op vrijdag 1 februari 2008 om 14.00 uur

door

Tatjana Seute

geboren 15 november 1971 te Heerlen 


\section{Promotores}

Prof.dr. M. Limburg

Prof.dr. M.H. Prins

Co-promotores

Dr. A. Twijnstra

Dr. G.P.M. ten Velde

Beoordelingscommissie

Prof.dr. E.F.M. Wouters (voorzitter)

Prof.dr.ir. P.A. van den Brandt

Prof.dr. P.E. Postmus (Vrije Universiteit, Amsterdam)

Prof.dr. V.C.G. Tjan-Heijnen

Dr. C.J. Vecht (Medisch Centrum Haaglanden, Den Haag) 


\section{Contents}

Chapter 1 Introduction ?

$\begin{array}{lll}\text { Chapter } 2 \text { Neurologic disorders in } 432 \text { consecutive patients with } & 13\end{array}$

Small Cell Lung Carcinoma

Chapter 3 Leptomeningeal metastases from Small Cell Lung Carcinoma:

frequencies and survival

Chapter 4 Detection of brain metastases from Small Cell Lung Cancer;

the consequences of changing imaging techniques

(CT versus MRI)

Chapter 5 First-line systemic chemotherapy for synchronous brain

metastases from Small Cell Lung Cancer: a systematic review

Chapter 6 Response of asymptomatic brain metastases from

Small Cell Lung Cancer to systemic first-line chemotherapy

Chapter? General discussion:

Clinical practice: Brain metastases from Small Cell Lung Cancer.

More questions than answers

Chapter 8 Summary and conclusions

Samenvatting en conclusies

Dankwoord

Curriculum vitae 

1

Introduction 



\section{Thesis outline}

Lung cancer is the primary cause of death from cancer worldwide. In the Netherlands, about 9.000 new lung cancer patients are diagnosed each year. Small Cell Lung Cancer (SCLC) presently accounts for approximately 13\% of all newly diagnosed lung cancer cases. ${ }^{1}$

The clinical behavior of SCLC differs from the more common non-small-cell cancers by its rapid growth and early development of widespread metastases. Despite high response rates to initial chemotherapy, nearly all patients will suffer from the development of chemotherapy resistance and ultimately die from their disease..$^{2 \cdot 4}$

Neurologic complications are encountered more frequently in SCLC patients than in other lung cancer patients. Earlier studies showed that in approximately one third of the SCLC patients at least one neurologic disorder is diagnosed. ${ }^{5,6}$ Especially the metastatic neurologic complications (brain and leptomeningeal metastases) contribute heavily to the morbidity and also possibly mortality in SCLC. ${ }^{7,8}$

In chapter 2 we describe the frequency of neurologic disorders and survival in 432 consecutive SCLC patients. Neurologic disorders were actively searched for through regular examinations by an experienced neurologist. Also imaging of the brain was performed routinely. We furthermore present the effect of brain metastases (BM) on the survival of SCLC patients. In chapter 3 the frequency of LMM in SCLC patients is described. In addition we investigate the effect of LMM on survival, whether the location of LMM is associated with survival and whether there is an increased risk of developing LMM among patients with $\mathrm{BM}$ in the posterior fossa.

BM are the most frequent neurologic disorder diagnosed in SCLC patients. ${ }^{?, 6}$ Chapter 4 focuses on the effect of changing from computer tomography (CT) to magnetic resonance imaging $(\mathrm{MRI})$ on the prevalence of detected $\mathrm{BM}$ in patients with newly diagnosed SCLC. We study the influence of this change on the prevalence of detected single BM and how this seems to affect prognosis. We furthermore assess how changing from CT to MRI influences the eligibility for, and effectiveness of prophylactic cranial irradiation. 
The optimal treatment of BM from lung cancer is an ongoing subject of debate..$^{9-11}$ On the basis of several papers published in the eighties and nineties, it has been suggested that BM from SCLC should initially be treated with systemic chemotherapy. ${ }^{12,13}$ In Chapter 5 we describe a systematic review in which we explore the role of systemic chemotherapy in the treatment of synchronous BM from SCLC. To further add relevant information for the debate, in chapter 6 we investigate the radiologic response of asymptomatic BM from to first-line systemic chemotherapy in 24 SCLC patients. In chapter 7 we describe a clinical case of a SCLC patient with synchronous asymptomatic BM. Proceeding from this case we elaborate on the treatment of asymptomatic BM and the usefulness of including MRI of the brain in the initial standard staging procedure in SCLC. In this chapter several important conclusions from earlier sections of this thesis are considered and discussed.

In chapter 8 we present, a summary of the results and conclusions described in this thesis along with the possible implications for current and future clinical care and research. 


\section{References}

1. Govindan R, Page N, Morgensztern D, et al: Changing epidemiology of small-cell lung cancer in the United States over the last 30 years: analysis of the surveillance, epidemiologic, and end results database. J Clin Oncol 24:4539-44, 2006

2. Osterlind K: Chemotherapy in small cell lung cancer. Eur Respir J 18:1026-43., 2001

3. Wolf M, Tebbe S, Fink T: First-line chemotherapy in metastatic small-cell lung cancer (SCLC). Lung Cancer 45 Suppl 2:S223-34, 2004

4. Jackman DM, Johnson BE: Small-cell lung cancer. Lancet 366:1385-96, 2005

5. Sculier JP, Feld R, Evans WK, et al: Neurologic disorders in patients with small cell lung cancer. Cancer 60:2275-83, 1987

6. Van Oosterhout AG, van de Pol M, ten Velde GP, et al: Neurologic disorders in 203 consecutive patients with small cell lung cancer. Results of a longitudinal study. Cancer 77:1434-41, 1996

7. Nugent JL, Bunn PA, Jr., Matthews MJ, et al: CNS metastases in small cell bronchogenic carcinoma: increasing frequency and changing pattern with lengthening survival. Cancer 44:1885-93, 1979

8. Wasserstrom WR, Glass JP, Posner JB: Diagnosis and treatment of leptomeningeal metastases from solid tumors: experience with 90 patients. Cancer 49:759-72., 1982

9. Schwer AL, Gaspar LE: Update in the treatment of brain metastases from lung cancer. Clin Lung Cancer 8:180-6, 2006

10. Girard N, Cottin V, Tronc F, et al: Chemotherapy is the cornerstone of the combined surgical treatment of lung cancer with synchronous brain metastases. Lung Cancer 53:51-8, 2006

11. Soffietti R, Costanza A, Laguzzi E, et al: Radiotherapy and chemotherapy of brain metastases. J Neurooncol 75:31-42, 2005

12. Grossi F, Scolaro T, Tixi L, et al: The role of systemic chemotherapy in the treatment of brain metastases from small-cell lung cancer. Crit Rev Oncol Hematol 37:61-7., 2001

13. Van den Bent MJ: The role of chemotherapy in brain metastases. Eur J Cancer 39:2114-20, 2003 



\section{2 \\ Neurologic disorders in 432 consecutive patients with Small Cell Lung Carcinoma}

Presented at the 54th annual meeting of the American Academy of Neurology, April 2002, Denver, USA

Tatjana Seute, Pieter Leffers, Guul P.M. ten Velde, Albert Twijnstra

Cancer 2004; 100: 801-806 


\section{Abstract}

\section{Background}

Neurologic complications are an important cause of morbidity and possibly also mortality in patients with small cell lung carcinoma (SCLC). The current study was undertaken to prospectively investigate survival and the frequency of neurologic disorders in patients with SCLC.

\section{Methods}

Between October 1980 and September 2001, 432 consecutive patients with microscopically proven SCLC were included in the current study. Patients underwent neurologic examinations on a regular basis prior to, during, and after treatment. Routine imaging of the brain (computed tomography or magnetic resonance imaging) was performed before and after systemic therapy.

\section{Results}

A neurologic disorder was diagnosed in approximately $56 \%$ of the SCLC patients. In nearly half of the cases, the neurologic disorder already was present at the time of diagnosis. Brain metastases (BM) were diagnosed most frequently. Seventy-four patients (18\%) had BM at the time of diagnosis; in 20 of these patients, the BM did not demonstrate clinical signs. Another 101 patients developed BM during follow-up. The 2-year cumulative risk of $\mathrm{BM}$ reached $49 \%$ for patients with limited disease (LD) and $65 \%$ for patients with extensive disease (ED). Patients with BM as the only site of disease dissemination were found to have a poorer survival compared with LD patients. The majority of the nonmetastatic disorders preceded the diagnosis of SCLC. The syndrome of inappropriate antidiuretic hormone secretion (SIADH) was diagnosed most frequently. 


\section{Conclusions}

In this prospective study, neurologic disorders were diagnosed in greater than half of the patients with SCLC. BM were detected most frequently. Approximately $18 \%$ of the patients were found to have BM at the time of diagnosis. In approximately $33 \%$ of the cases, these BM did not cause symptoms. BM were found to have a negative effect on survival in patients with SCLC. 


\section{Introduction}

In 2000, it was estimated that 164,100 new cases of lung carcinoma are diagnosed per year in the U.S., with 159,900 deaths from the disease reported annually. ${ }^{1}$ Of all incident cases of lung carcinoma, approximately $20-25 \%$ are reported to be small cell lung carcinoma $(S C L C)^{2}$

The incidence of SCLC in the Netherlands is 15.3 (per 100,000 persons age 16 years). ${ }^{3}$ Despite new treatment regimens, survival remains poor. ${ }^{4}$ This is due in part to the neuroendocrine phenotype of SCLC, which distinguishes it from other types of lung carcinoma. These neuroendocrine properties are most likely responsible for the unique behavior of SCLC, which includes metastatic activity to the central nervous system (CNS) and the generation of paraneoplastic syndromes. ${ }^{5}$ Neurologic complications frequently are reported in patients with SCLC and are believed to contribute heavily to morbidity as well as mortality. 6,7 With a prevalence of approximately $10 \%$, brain metastases (BM) are the most common neurologic complication diagnosed in patients with SCLC. Another $40 \%$ of patients have been reported to develop BM during follow-up. ${ }^{8}$ The probability of developing BM increases to $50-80 \%$ at 2 years from diagnosis. ${ }^{9}$

The current study was undertaken to prospectively investigate survival and the frequency of neurologic disorders in patients with SCLC. Patients were followed prospectively, and neurologic disorders were actively searched for. The current study is a continuation of a previously published study. ${ }^{6}$ Because the current study included a larger number of patients, it allowed a more detailed analysis to be performed.

\section{Materials and methods}

\section{Patients}

Between October 1980 and September 2001, 432 consecutive patients with microscopically and histologically proven SCLC were enrolled in the current study. Patients 
were diagnosed and treated at the University Hospital Maastricht (The Netherlands). Potential follow-up for each patient was at least 1 year. Patients initially were staged by a pulmonologist; physical examination, routine blood and chemistry profile, chest X-ray, computed tomography (CT) scan of the chest, and fiberoptic bronchoscopy were performed routinely. Limited disease (LD) was defined as tumor confined to one hemithorax, the mediastinum, and the ipsilateral and/or contralateral scalene and supraclavicular lymph nodes. Tumor occurring beyond these sites was defined as extensive disease (ED).

Table 1. Patient Characteristics at the Time of Diagnosis and Frequency of Metastases outside

\begin{tabular}{|l|c|c|c|c|}
\hline \multirow{2}{*}{} & \multicolumn{4}{|c|}{ Disease stage } \\
\cline { 2 - 6 } & Limited & $\%$ & Extensive & $\%$ \\
\hline Total & 140 & & 292 & \\
\hline Men & 102 & 73 & 245 & 84 \\
\hline Median age (yrs)(range) & $65(32-80)$ & & $66(39-89)$ & \\
\hline Metastases (not in CNS) & 136 & 97 & 20 & 7 \\
\hline None & & & 144 & 49 \\
\hline Bone & & & 148 & 51 \\
\hline Liver & & & 62 & 21 \\
\hline Mediastinum & 4 & 3 & 115 & 39 \\
\hline Other & \multicolumn{4}{|l}{} \\
\hline
\end{tabular}

CNS: central nervous system

\section{Neurologic Follow-Up}

All patients were examined by a neurologist at the time of diagnosis, every 3 months during the first year, and every 6 months thereafter. Imaging of the brain was performed before and after treatment. An additional brain scan was performed when patients had survived for 12 months after the initial diagnosis of SCLC. Until 1989, CT scans were used. After 1989, CT was replaced by magnetic resonance imaging (MRI). In the case of new 
neurologic symptoms or signs developing, neurologic consultations and diagnostics were performed more frequently.

\section{Treatment}

Initial treatment was comprised of combination chemotherapy using cyclophosphamide, doxorubicin, and etoposide. This combination was repeated at 3-4week intervals, with a maximum of 5 courses. The actual number of courses depended on the clinical condition of the patient. Local radiotherapy occasionally was applied to

\section{Table 2. Treatment and Response}

\begin{tabular}{|l|c|c|c|c|c|c|c|}
\hline \multirow{2}{*}{} & \multicolumn{6}{|c|}{ Disease stage } \\
\cline { 2 - 8 } & Limited & $\%$ & Extensive & $\%$ & Total & $\%$ \\
\hline Chemotherapy & 127 & 94 & 239 & 86 & 366 & 88 \\
\hline Yes & 8 & 6 & 40 & 14 & 48 & 12 \\
\hline No & 2 & & 2 & & 4 & \\
\hline Unknown & 3 & & 11 & & 14 & \\
\hline Dead & 140 & & 292 & & 432 & \\
\hline Total & & & & & \\
\hline Response & 68 & 56 & 66 & 30 & 134 & 39 \\
\hline CR & 33 & 27 & 88 & 40 & 121 & 35 \\
\hline PR & 11 & 9 & 18 & 8 & 29 & 8 \\
\hline SD & 9 & 7 & 50 & 23 & 59 & 17 \\
\hline PD & 6 & & 17 & & 23 & \\
\hline Unknown & & & & & & \\
\hline Total & 127 & & 239 & & 366 & \\
\hline Radiotherapy to the brain & 25 & & 65 & & 90 & \\
\hline Prophylactic cranial irradiation & 35 & & 10 & & 45 & \\
\hline
\end{tabular}

CR: complete remission; PR: partial remission; SD: stable disease; PD: progressive disease. $a=$ Patients died before evaluation of result. 
the primary tumor after chemotherapy; no strict indication criteria were established for this treatment. Response after initial treatment was measured using standard criteria. Complete remission (CR) was defined as the total clinical and radiologic resolution of the disease. A reduction of at least $50 \%$ of all measurable lesions was regarded as a partial remission (PR). The remainder of responses were regarded as no response (stable disease or progressive disease).

Patients in CR were eligible for prophylactic cranial irradiation (PCI). Until 1986, both patients with LD and those with ED could opt for PCI. After 1986, only patients with LD could do so. Between 1990-1997, PCI was excluded from the treatment protocol. PCl was administered to the entire brain after the completion of the chemotherapy. The total dose was 30 grays (Gy), administered as either 3 Gy given 4 times a week or 2 Gy given 5 times a week. Clinically manifest BM were treated with whole brain radiotherapy with fractions of $3 \mathrm{~Gy}$ given 4 times a week, also up to $30 \mathrm{~Gy}$ in total dose. In the case of cerebral edema, patients received corticosteroid medication.

Patients with leptomeningeal metastases were treated with intrathecal methotrexate, systemic chemotherapy, or local radiotherapy at symptomatic sites. Therapy for epidural or intramedullar spinal metastases was comprised of radiotherapy combined with corticosteroids.

Patient characteristics and details regarding treatment are shown in Tables 1 and 2.

\section{Statistical Analysis}

Survival curves were estimated using the Kaplan-Meier method. Differences between survival curves were tested with the log-rank test. A P value $<0.05$ was considered to be statistically significant. Survival was calculated from the date of diagnosis of SCLC. BM-free survival time was calculated from the date of the diagnosis of SCLC to the date of the diagnosis of BM, and patients were censored from the moment they died. 


\section{Results}

A total of 432 patients were included, 292 of whom (68\%) were staged as having

Table 3. Neurologic Disorders at Date of Diagnosis of SCLC

\begin{tabular}{|c|c|c|c|c|}
\hline & $\begin{array}{l}\text { Limited } \\
\text { disease }\end{array}$ & $\begin{array}{c}\text { Extensive } \\
\text { disease }\end{array}$ & Total & $\%$ \\
\hline No. of patients & 140 & 292 & 432 & \\
\hline \multicolumn{5}{|l|}{ Metastatic disorders } \\
\hline \multicolumn{5}{|l|}{ Brain metastases } \\
\hline No brain metastases & 140 & 168 & 308 & 71 \\
\hline Symptomatic brain metastases & & 43 & 43 & 10 \\
\hline Asymptomatic brain metastases & & 20 & 20 & 5 \\
\hline Brain metastases at autopsy & & 11 & 11 & 3 \\
\hline Unknown & 0 & 5 & 5 & - \\
\hline No brain scan performed & 0 & 45 & 45 & 10 \\
\hline Other metastases $(\mathrm{CNS})(\mathrm{n}=18$ patients $)$ & & & & 4 \\
\hline Leptomeningeal metastases & & 8 & 8 & \\
\hline Epidural metastases & & 9 & 9 & \\
\hline Intramedular metastases & & 1 & 1 & \\
\hline Nonmetastatic disorders ( $n=37$ patiens) & & & & 9 \\
\hline SIADH & 2 & 22 & 24 & \\
\hline Polyneuropathy & 1 & 1 & 2 & \\
\hline Lambert-Eaton myasthenic syndrome & 3 & 4 & 7 & \\
\hline Subacute cerebellar degeneration & 1 & 0 & 1 & \\
\hline Limbic encephalitis & 1 & 2 & 3 & \\
\hline
\end{tabular}

SCLC: small cell lung carcinoma; CNS: central nervous system; SIADH: syndrome of inappropriate antidiuretic hormone secretion. 
ED. Table 3 shows the neurologic disorders apparent at the time of diagnosis. Disorders that were diagnosed within 4 weeks after the diagnosis of SCLC was made were considered to be present at the time of the initial diagnosis of SCLC. Seventy-four patients (18\%) were found to have BM at the time of diagnosis (synchronous); in 20 patients, these BM did not appear to cause clinical signs (asymptomatic). In 11 patients, BM were found at the time of autopsy, during which SCLC was diagnosed as well. Forty-five patients did not undergo a brain scan because their clinical condition was too poor and/or they died shortly after the diagnosis of SCLC was made. For another five patients, we were unable to ascertain data regarding diagnostic procedures. Other neurologic metastatic disorders were found in 17 patients. One patient had both leptomeningeal metastases and epidural metastases. Of all nonmetastatic disorders, syndrome of inappropriate antidiuretic hormone (ADH) secretion

Table 4. Lifetime Incidence of Neurologic Disorders Developing During Follow-Up

\begin{tabular}{|c|c|c|c|c|}
\hline & $\begin{array}{l}\text { Limited } \\
\text { disease }^{\mathrm{ab}}\end{array}$ & $\%$ & $\begin{array}{l}\text { Extensive } \\
\text { disease }^{a b}\end{array}$ & $\%$ \\
\hline \multicolumn{5}{|l|}{ Metastatic disorders } \\
\hline Symptomatic brain metastases & $38 / 136$ & 28 & $63 / 127$ & 50 \\
\hline Leptomeningeal metastases & $11 / 136$ & 8 & $18 / 243$ & 7 \\
\hline Epidural metastases & $2 / 136$ & 1 & $13 / 242$ & 5 \\
\hline Intramedular metastases & $1 / 136$ & 1 & $3 / 250$ & 1 \\
\hline \multicolumn{5}{|l|}{ Nonmetastatic disorders } \\
\hline SIADH & $6 / 134$ & 4 & $0 / 229$ & 0 \\
\hline Polyneuropathy & $2 / 135$ & 1 & $3 / 250$ & 1 \\
\hline Lambert-Eaton myasthenic syndrome & $3 / 133$ & 2 & $0 / 247$ & 0 \\
\hline Subacute cerebellar degeneration & $0 / 135$ & 0 & $0 / 250$ & 0 \\
\hline Limbic encephalitis & $0 / 135$ & 0 & $0 / 249$ & 0 \\
\hline
\end{tabular}

SIADH: syndrome of inappropriate antidiuretic hormone secretion.

$a=$ Stage of disease at the time of the initial diagnosis of small cell lung carcinoma.

$b=$ The denominator accounts for all patients in this stage of disease who were alive 4 weeks, minus those patients already diagnosed with the respective neurologic disorder. 
(SIADH) was found most frequently.

The denominators in Table 4 account for all patients with LD or ED who were alive 4 weeks after diagnosis, minus those patients already diagnosed with the specific neurologic disorder involved. A total of 45 patients $(10 \%)$ died within 4 weeks of the diagnosis of SCLC. As described in Table 4, 101 patients developed symptomatic BM during follow-up (metachronous). In 59 patients, it remains unknown whether they developed symptomatic BM, in part because they did not undergo a second brain scan because of their poor clinical condition or early death.

Twenty-nine patients developed leptomeningeal metastases during follow-up and 8 cases were detected at the time of diagnosis. In 23 patients with leptomeningeal metastases, BM were present as well (62\%).

Figure 1. Kaplan-Meier curves showing survival after the date of diagnosis of small cell lung carcinoma (SCLC) in patients with limited disease (LD) and extensive disease (ED). The asterisk [ ${ }^{*}$ ] indicates all patients minus those patients diagnosed with SCLC at autopsy.

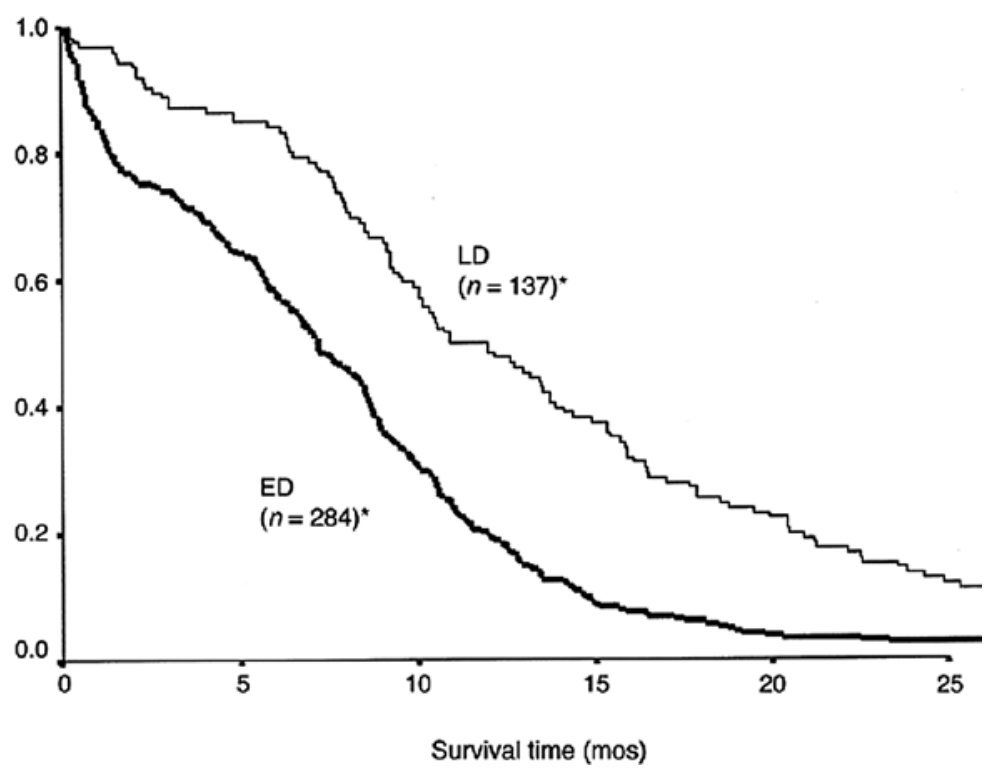


The majority of nonmetastatic disorders preceded the diagnosis of SCLC. SIADH was diagnosed most frequently, followed by the Lambert-Eaton myasthenic syndrome.

The median survival time in the current study group $(n=421)$ was 8.5 months (range, 0-154 months). The median survival of those patients treated with chemotherapy ( $n=127$ ) was 9.2 months (range, 0-154 months). As expected, survival in the patients with ED was shorter than that in the patients with LD $(P<0.0005)$ (Fig. 1). The median survival for patients with ED ( $\mathrm{n}=284$ ) was 7.2 months (range, 0-124 months), whereas that for patients with $\operatorname{LD}(\mathrm{n}=137)$ was 11.9 months (range, 0-154 months). As shown in Figure 2, patients with BM only (patients with ED in whom the brain was the only site of disease dissemination $)$ had a poorer survival than patients with $L D(P<0.0005)$. Patients with BM only $(n=20)$ had a median survival of 6.1 months (range, 0-32 months).

Figure 2. Kaplan-Meier survival curves showing survival from the date of diagnosis of small cell lung carcinoma of patients with extensive disease (ED), patients with brain metastases (BM) only, and patients with limited disease (LD).

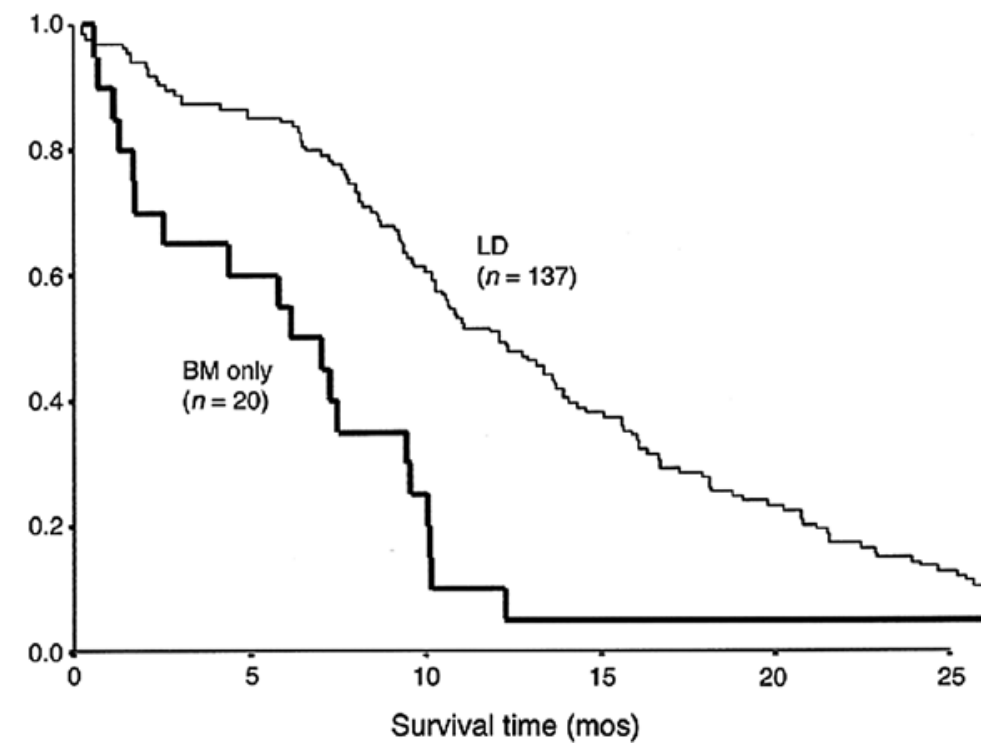


Figure 3. Kaplan-Meier survival curves showing brain metastases-free survival from the date of diagnosis of small cell lung carcinoma in patients with limited disease (LD) and those with extensive disease (ED).

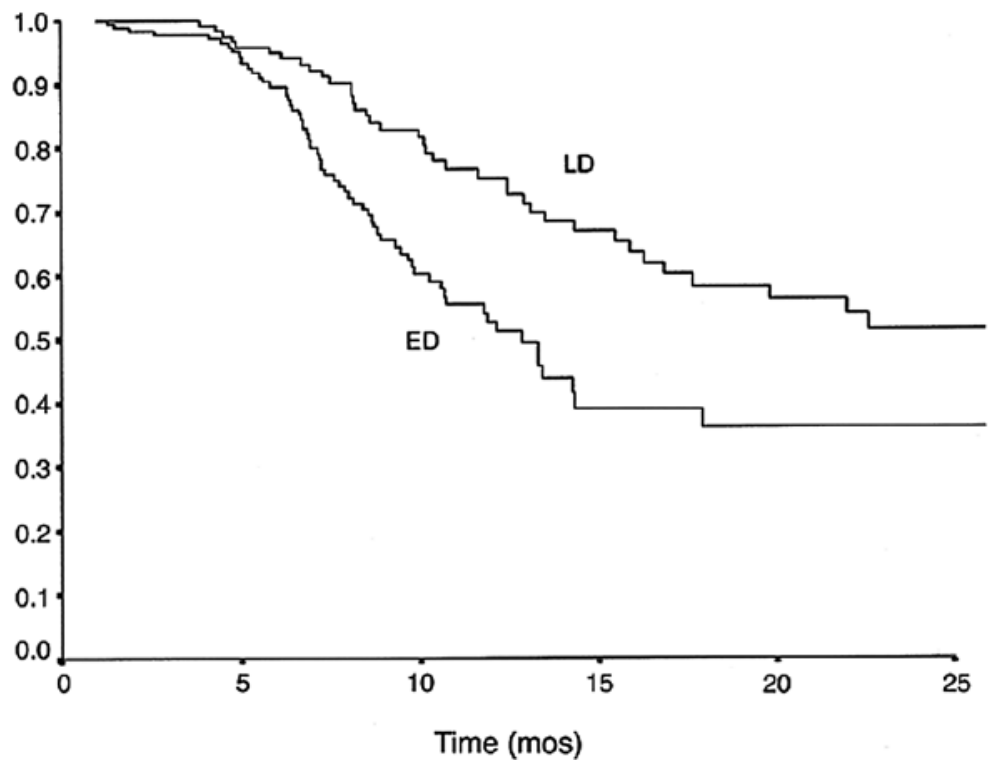

The 2-year cumulative risk of BM among patients who were free of BM at the time of SCLC diagnosis was $49 \%$ for patients with LD and $65 \%$ for patients with ED (Fig. 3).

Of the SCLC patients with BM, 170 died within the study period. The causes of death are described in Table 5. In 59 patients, death was considered an immediate result of BM (intracranial hypertension). The cause of death remained unknown in 45 patients who died at home. Categorized as other are causes such as sepsis, dehydration, and myocardial ischemia.

During the period in which $\mathrm{Cl}$ was excluded from the treatment protocol (19901997), the 1-year cumulative incidence of BM after the diagnosis of SCLC was 33\%. During the period in which $\mathrm{PCl}$ was applied, the 1-year cumulative incidence after the diagnosis of SCLC was $23 \%$. 
Table 5. Causes of Death in SCLC Patients with Brain Metastases

\begin{tabular}{|c|c|c|}
\hline & No. & $\%$ \\
\hline No. of deceased patients & 170 & \\
\hline \multicolumn{3}{|l|}{ Cause of death } \\
\hline \multicolumn{3}{|l|}{ Neurologic } \\
\hline - Brain & 59 & 47 \\
\hline \multicolumn{3}{|l|}{ Nonneurologic } \\
\hline - Lung & 21 & 17 \\
\hline - Liver & 4 & 3 \\
\hline - Other & 7 & 6 \\
\hline - Not specified ${ }^{a}$ & 34 & 27 \\
\hline Unknown & 45 & \\
\hline
\end{tabular}

SCLC: small cell lung carcinoma.

$\mathrm{a}=$ Death was not caused by brain metastases, but was not specified further. 


\section{Discussion}

In the current study, 240 SCLC patients (56\%) were diagnosed with a neurologic disorder at some point during their disease. In nearly half of the cases, the neurologic disorder already was present at the time of diagnosis. A higher frequency of BM was observed in comparison with earlier studies (18\% vs. 10\%). ${ }^{8-10}$ This most likely is due at least in part to differences in the diagnostic procedures utilized in the initial staging. CT scan and later MRI were used routinely in the pretreatment evaluation in the current study, which led to the identification of asymptomatic BM.

During follow-up, another 101 patients developed symptomatic BM. The lifetime incidence was lower among patients with LD compared with patients with ED.

It has been reported that BM as such do not negatively influence the prognosis for patients with SCLC. ${ }^{11,12}$ However, we found that patients with ED who had only BM had a poorer survival than patients with LD (Fig. 2). In addition, in nearly half of the patients with $\mathrm{BM}$, the cause of death was found to be related directly to the BM (Table 5). We therefore argue that BM have an adverse effect on survival in patients with SCLC.

Comparing periods in which $\mathrm{PCl}$ was administered with those in which it was not administered, we found that the cumulative incidence of BM was higher during the period in which $\mathrm{PCl}$ was not administered. This supports the findings of other authors who have reported that $\mathrm{PCl}$ may decrease the incidence of $\mathrm{BM} .^{13,14}$

Leptomeningeal metastases were diagnosed for the most part during follow-up. In total, we found 37 patients with leptomeningeal metastases, which was $9 \%$ of the total patient group in the current study. Previously reported percentages have been reported to vary from $6-18 \%$. ${ }^{6,7,15,16}$

Ten patients were found to have spinal metastases at the time of diagnosis. During follow-up, another 15 patients were diagnosed with epidural metastases and 4 patients were diagnosed with intramedullar metastases. In all patients with intramedullar 
metastases, BM already were present. Earlier studies also reported low frequencies of spinal metastases in patients with SCLC. ${ }^{6,7,17}$

Because of its neuroendocrine properties, SCLC is associated more frequently with paraneoplastic syndromes compared with other malignancies. ${ }^{18-21}$ In the current study, $9 \%$ of patients were found to have a nonmetastatic paraneoplastic disorder at the time of diagnosis of SCLC. SIADH was diagnosed in 30 patients, a frequency that is similar to the findings of other investigators. ${ }^{19}$ The results of the current study confirm earlier findings, which demonstrated that paraneoplastic syndromes frequently precede the diagnosis of SCLC. ${ }^{22}$

The median survival in the current study, which was reported to be 11.9 months in patients with LD and 7.2 months in patients with ED, is in accordance with the findings of earlier studies. ${ }^{4,6,23}$

\section{Conclusions}

Among the conclusions reached in the current study are: 1) at the time of diagnosis of SCLC, $18 \%$ of the patients in the current study had BM; however, these BM caused no symptoms in approximately a third of the cases; 2 ) contrary to reports in the literature, BM appear to have a negative effect on survival in patients with SCLC; and 3] BM are the direct cause of death in nearly half of the patients with BM. 


\section{References}

1 Greenlee RT, Murray T, Bolden S, Wingo PA. Cancer statistics. CA Cancer J Clin . 2000; 50: 7-33.

2 Boring CC, Squires TS, Tong T, Montgomery S. Cancer statistics. CA Cancer J Clin . 1994; 44: 7-26.

3 Netherlands Cancer Registry. Lung cancer and mesothelioma in the Netherlands, 1989 1997. Amsterdam: Netherlands Cancer Registry, 1997.

4 Paesmans M, Seulter J, Lecomte J, et al. Prognostic factors for patients with small cell lung carcinoma: analysis of a series of 763 patients included in 4 consecutive prospective trials with a minimum follow-up of 5 years. Cancer . 2000; 89: 523-533.

$5 \quad$ Williams CL. Basic science of small cell lung cancer. Chest Surg Clin N Am . 1997; 7: 1-15.

6 Van Oosterhout AG, van de Pol M, ten Velde GPM, Twijnstra A. Neurologic disorders in 203 consecutive patients with small cell lung cancer. Results of a longitudinal study. Cancer . 1996; 77: 1434-1441.

7 Sculier J, Feld R, Evans WK, et al. Neurologic disorders in patients with small cell lung cancer. Cancer . 1987; 60: 2275-2283.

8 Newman S. Frequency, diagnosis, and treatment of brain metastases in 249 consecutive patients with bronchogenic carcinoma. Cancer . 1974; 33: $492-496$.

9 Nugent J. CNS metastases in small cell bronchogenic carcinoma: increasing frequency and changing pattern with lengthening survival. CA Cancer J Clin . 1976; 44: 1885-1893.

10 Hirsch FR, Osterlind K, Hansen HH. Intracranial metastases in small cell carcinoma of the lung. Prognostic aspects. Cancer. 1983; 51: 529-533.

11 Kochhar R, Frytak S, Shaw EG. Survival of patients with extensive small-cell lung cancer who have only brain metastases at initial diagnosis. Am J Clin Oncol . 1997; 20: 125-127.

12 Van Hazel GA, Scott M, Eagan RT. The effect of CNS metastases on the survival of patients with small cell cancer of the lung. Cancer. 1983; 51: 933-937.

13 Meert AP, Paesmans M, Berghmans T, et al. Prophylactic cranial irradiation in small cell lung cancer: a systemic review of the literature with meta-analysis. BMC Cancer . 2001; 1: 5. 
14 Auperin A, Arrigada R, Pignon JP, et al. Prophylactic cranial irradiation for patients with smallcell cancer in complete remission. Prophylactic Cranial Irradiation Overview Collaborative Group. N Engl J Med . 1999; 341: 524-526. Rosen ST, Aisner J, Makuch RW, et al. Carcinomatous leptomeningitis in small cell lung cancer: a review of the National Cancer Institute experience. Medicine . 1982; 61: 45-53. Aroney RS, Dalley DN, Chan WK, Bell DR, Levi JA. Meningeal cancer in small cell carcinoma of the lung. Am J Med . 1981; 71: 26-32. Weissman DE, Grossman SA. Simultaneous leptomeningeal and intramedullary spinal metastases in small cell lung carcinoma. Med Pediatr Oncol . 1986; 14: 54-56. Mason WP, Graus F, Lang B, et al. Small-cell lung cancer, paraneoplastic cerebellar degeneration and the Lambert-Eaton myasthenic syndrome. Brain . 1997; 120(Pt 8): 1279 1300 .

19 List AF, Hainsworth JD, Handek R, Greco FA, Johnson DH. The syndrome of inappropriate secretion of antidiuretic hormone (SIADH) in small-cell lung cancer. J Clin Oncol . 1986; 4: 1191-1198.

Elrington GM, Murray NM, Spiro SG, Newsom-Davis J. Neurological paraneoplastic syndromes in patients with small cell lung cancer. A prospective survey of 150 patients. J Neurol Neurosurg Psychiatry. 1991; 54: 764-767.

21 Dropcho EJ. Autoimmune central nervous system paraneoplastic disorders: mechanisms, diagnosis, and therapeutic options. Ann Neurol . 1995; 37 (Suppl 1): S102-S113. Anderson NE, Rosenblum MK, Graus F, Wiley RG, Posner JB. Autoantibodies in paraneoplastic syndromes associated with small-cell lung cancer. Neurology . 1988; 38: 1391-1398.

23 Dearing MP, Steinberg SM, Phelps R, et al. Outcome of patients with small-cell lung cancer: effect of changes in staging procedures and imaging technology on prognostic factors over 14 years. J Clin Oncol . 1990; 8: 1042-1049. 



\section{3 \\ Leptomeningeal metastases from Small Cell Lung Carcinoma Frequencies and survival}

Presented at the 55th annual meeting of the American Academy of Neurology, April 2003, Honolulu, Hawaii

Tatjana Seute, Pieter Leffers, Guul P.M ten Velde, Albert Twijnstra

Cancer 2005; 104: 1700-1705 


\begin{abstract}
Background

The current study was performed to investigate the frequency of leptomeningeal metastases (LMM) in patients with small cell lung carcinoma (SCLC) as well as the effect of LMM on survival, any correlation between the location of the LMM and survival, and a possible increased risk of LMM among patients with brain metastases (BM) located in the posterior fossa.
\end{abstract}

\title{
Methods
}

Between 1980-2003, 458 consecutive patients with SCLC were enrolled in the current study. Patients underwent regular neurologic examination and imaging of the brain before, during, and after treatment. The diagnosis of LMM was established by either the presence of malignant cells in the cerebrospinal fluid or positive clinical symptoms and signs supported by radiologic findings on magnetic resonance imaging.

\section{Results}

The group of patients in the current study had a $2 \%$ prevalence of LMM and the 2-year cumulative incidence of LMM was found to be $10 \%$. The median survival after the diagnosis of LMM was reported to be 1.3 months. The median survival among patients with LMM located in the spinal cord was 2.4 months. The reported LMM-free survival 2 years after the diagnosis of SCLC was 78\% for patients without BM and 61\% for those patients with BM. Approximately $15 \%$ of the patients with BM located in the posterior fossa developed LMM, whereas only $10 \%$ of patients with cerebral BM did.

\section{Conclusions}

The current prospective study found a 2-year cumulative incidence of LMM of $10 \%$, with a prevalence of $2 \%$. Patients with LMM located in the spinal cord appeared to survive longer than patients with cranial LMM. SCLC patients with BM located in the posterior fossa may be at a higher risk of developing LMM compared with patients with cerebral BM. 


\section{Introduction}

Leptomeningeal metastases (LMM) are a devastating complication of malignancy, affecting patients with both solid tumors and hematologic malignancies. The prognosis from the time of the diagnosis of LMM is poor, with patients reported to survive 1-6 months. ${ }^{1,2}$ The solid tumors that most frequently give rise to LMM are breast carcinoma, melanoma, and lung carcinoma. ${ }^{3-6}$ There is some evidence that the frequency of LMM is increasing, most likely due to patients surviving longer as a result of more aggressive and effective treatment of the primary tumor. The use of better neuroimaging techniques also may contribute to a higher rate of detection?

The reported frequencies of LMM among cancer patients have been reported to vary from $2-15 \%$ in different studies. ${ }^{3}$ To our knowledge, only a few studies to date have reported the frequencies of LMM in homogeneous patient groups with one solid tumor. These studies have estimated leptomeningeal involvement to occur in approximately 2-5\% of all patients with breast carcinoma, $9-25 \%$ of all patients with small cell lung carcinoma (SCLC), and $23 \%$ of all patients with melanoma. ${ }^{8-11}$ However, a disadvantage of studies concerning the frequencies of LMM that have been published to date is that they are based on data that were collected from historical patient files. Because the clinical diagnosis of LMM, especially in the early stages, is difficult to establish, it is possible that such diagnoses may not have been recognized and therefore were not included in patient files. Therefore, the frequencies of LMM may have been underestimated in these studies.

The current study focused on SCLC, which is reported to comprise $20-25 \%$ of all lung carcinoma cases. Neurologic complications, including metastatic activity to the central nervous system (CNS), are a frequent finding in this tumor entity. ${ }^{12}$ This behavior is in part considered to be the result of the neuroendocrine phenotype of SCLC. ${ }^{13}$ In this study, we included SCLC patients who all were seen regularly by a neurologist and in whom imaging of the brain was routinely performed. Therefore, neurologic complications, including dissemination to the CNS, were actively searched for. The current study therefore was expected to yield a more accurate estimation of the frequency of LMM in patients with SCLC. Additional aims of this study were to investigate the following objectives: 1) What is 
the effect of LMM on survival? 2) Is the location of the LMM correlated with survival? 3) Is there an increased risk of developing LMM among patients with brain metastases (BM) located in the posterior fossa?

\section{Materials and methods}

\section{Patients}

Between October 1980 and January 2003, 458 consecutive patients with microscopically and histologically proven SCLC were enrolled in the current study. Patients were diagnosed and treated at the University Hospital Maastricht (Maastricht, The Netherlands]. Potential follow-up for each patient was at least 1 year. Patients initially were staged by a pulmonologist and physical examination, routine blood and chemistry profile, chest X-ray, computed tomography (CT) scan of the chest, and fiberoptic bronchoscopy were routinely performed. Limited disease was defined as tumor confined to one hemithorax, the mediastinum, and the ipsilateral and/or contralateral scalene and supraclavicular lymph nodes. Tumor occurring beyond these sites was defined as extensive disease (ED).

\section{Neurologic Follow-Up}

All patients were examined by a neurologist at the time of diagnosis and every 3 months during the first year and every 6 months after 1 year. Imaging of the brain was performed before and after initial treatment, which was comprised of combination chemotherapy (cyclophosphamide, doxorubicin, and etoposide). An additional brain scan was performed when patients had survived for 12 months after the diagnosis of SCLC. CT scans were used until 1989, after which CT was replaced by magnetic resonance imaging (MRI). In the event of new neurologic symptoms or signs, neurologic consultations and diagnostic tests were performed more frequently.

If neurologic symptoms and signs involved more than one site of the neuroaxis, we considered a diagnosis of LMM. The diagnosis of LMM was established by the presence 
of malignant cells in the cerebrospinal fluid (CSF). Lumbar puncture was repeated up to three times when the first and/or second CSF sample was negative. MRI scanning of the brain and spine was performed in all patients with suspected LMM. If the CSF was not obtained or if cytology was negative, positive clinical symptoms and signs supported by typical radiologic findings on gadolinium-enhanced MRI scans established the diagnosis of LMM. The location of the LMM was divided into cranial, spinal cord, and both cranial and spinal cord. This division was made based on clinical symptoms and signs, combined with imaging features if available.

\section{Treatment}

LMM were treated in those patients with a Karnofsky performance score of at least 70. Treatment was comprised of radiotherapy (in the case of bulky disease), systemic chemotherapy, or intra-CSF chemotherapy (methotrexate).

\section{Statistical Analysis}

Survival curves were estimated using the Kaplan-Meier method. Differences between survival curves were tested using the log-rank test. A $P$ value less than 0.05 was

Table1. Patient Characteristics at the Time of Diagnosis of SCLC

\begin{tabular}{|l|c|c|}
\hline Characteristic & Total $(\mathrm{n}=458)$ & $\%$ \\
\hline Median age in yrs (range) & $61(32-99)$ & \\
\hline Male gender & 357 & 78 \\
\hline ED & 319 & 70 \\
\hline Symptomatic BM & 49 & 11 \\
\hline Asymptomtic BM & 24 & 5 \\
\hline LMM & 9 & 2 \\
\hline Liver metastases & 154 & 34 \\
\hline Bone metastases & 151 & 33 \\
\hline
\end{tabular}

SCLC: small cell lung carcinoma; ED: extensive disease; BM: brain metastases; LMM: leptomeningeal metastases. 
considered to be statistically significant. Survival was calculated either from the date of the diagnosis of SCLC or the date of the diagnosis of LMM. LMM-free survival time was calculated from the date of the diagnosis of SCLC to the date of the diagnosis of LMM; patients were censored from the date of death.

\section{Results}

A total of 458 patients were included, 319 of whom [70\%) were classified as having ED. Patient characteristics at the time of the diagnosis of SCLC are shown in Table 1. Disorders that were diagnosed within 4 weeks after the diagnosis of SCLC were considered to be present at the time of the initial diagnosis of SCLC. The prevalence of LMM in the patient group in the current study was $2 \%$ because 9 patients were found to have LMM at the time of the diagnosis of SCLC. In three of these patients, LMM were diagnosed before the diagnosis of SCLC had been made. One patient diagnosed with LMM died within 4 weeks. A total of 371 patients survived for longer than 4 weeks and were not diagnosed with LMM at the time of the diagnosis of SCLC. Thirty-six patients developed LMM during the follow-up period. The 2-year cumulative incidence of LMM was therefore 10\% (36 of 371 patients]. The median time from the diagnosis of SCLC to the diagnosis of LMM was 8.2 months (range, 0-18 months).

Table 2 shows how the diagnosis of LMM was made. In nearly half of the patients (48\%), the diagnosis of LMM was established by imaging combined with positive clinical symptoms and signs. At least 1 lumbar puncture was performed in 27 of the 45 patients diagnosed with LMM. As shown in Table 2, malignant cells were found in 18 patients (67\%). Sixty-five of the 438 patients who died underwent autopsy (15\%); LMM were found in 5 of these patients $[8 \%]$.

The median survival after the diagnosis of LMM was 1.3 months (range, 0.2-25.3 mos) (Fig. 1). Figure 2 shows survival from the time of the diagnosis of SCLC in patients in whom LMM were found during the follow-up period compared with patients without LMM. There were no significant differences noted in survival $(P=0.7863)$. 
Table 2. TClinical Sites of Neuroaxis Involvement and Diagnostic Tools in 45 SCLC Patients with LMM

\begin{tabular}{|l|c|c|c|c|c|}
\hline \multirow{2}{*}{ Sites } & \multicolumn{5}{|c|}{ Diagnostic tool } \\
\cline { 2 - 6 } & Total & Cytology & Imaging & Both $^{\text {a }}$ & Autopsy \\
\hline LMM & 15 & 3 & 7 & 3 & 2 \\
\hline LMM + BM & 25 & 6 & 9 & 6 & 3 \\
\hline LMM + epidural metastases $^{*}$ & 1 & - & 1 & - & - \\
\hline LMM + BM + cord lesions $^{\text {b }}$ & 5 & - & 5 & - & - \\
\hline Total & 45 & 9 & 22 & 9 & 5 \\
\hline
\end{tabular}

SCLC: small cell lung carcinoma; LMM: leptomeningeal metastases; BM: brain metastases.

a Cytology and imaging.

b Epidural metastases and intramedullary metastases.

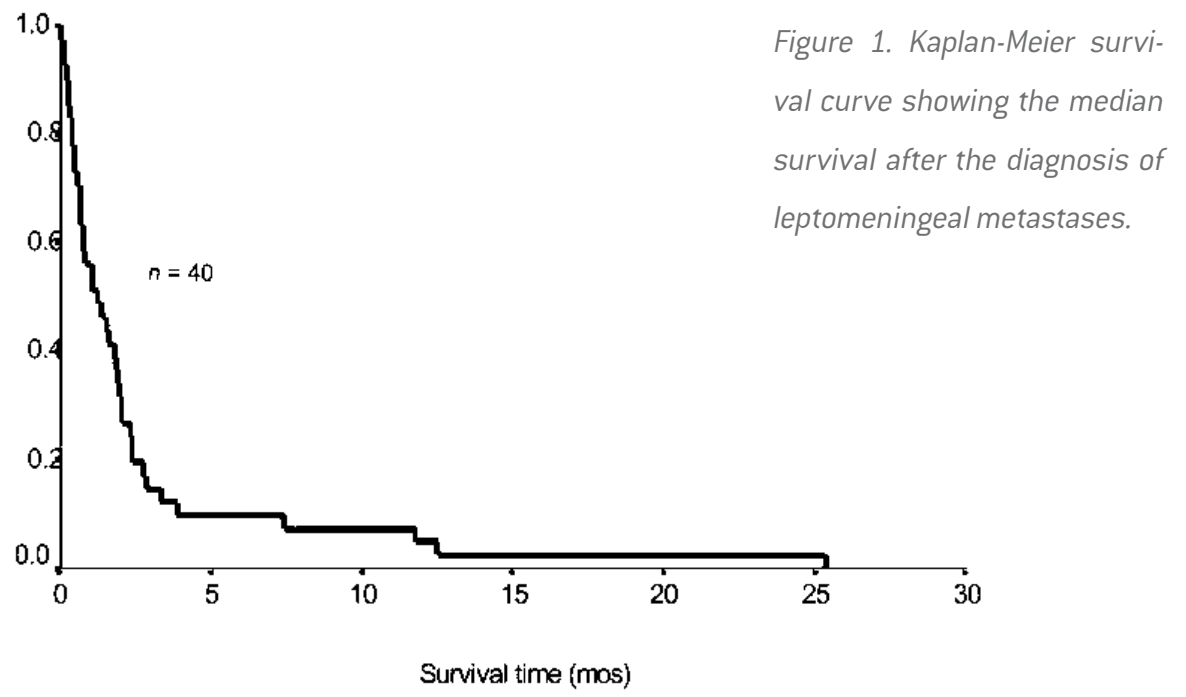


Figure 2. Kaplan-Meier survival curves showing survival from

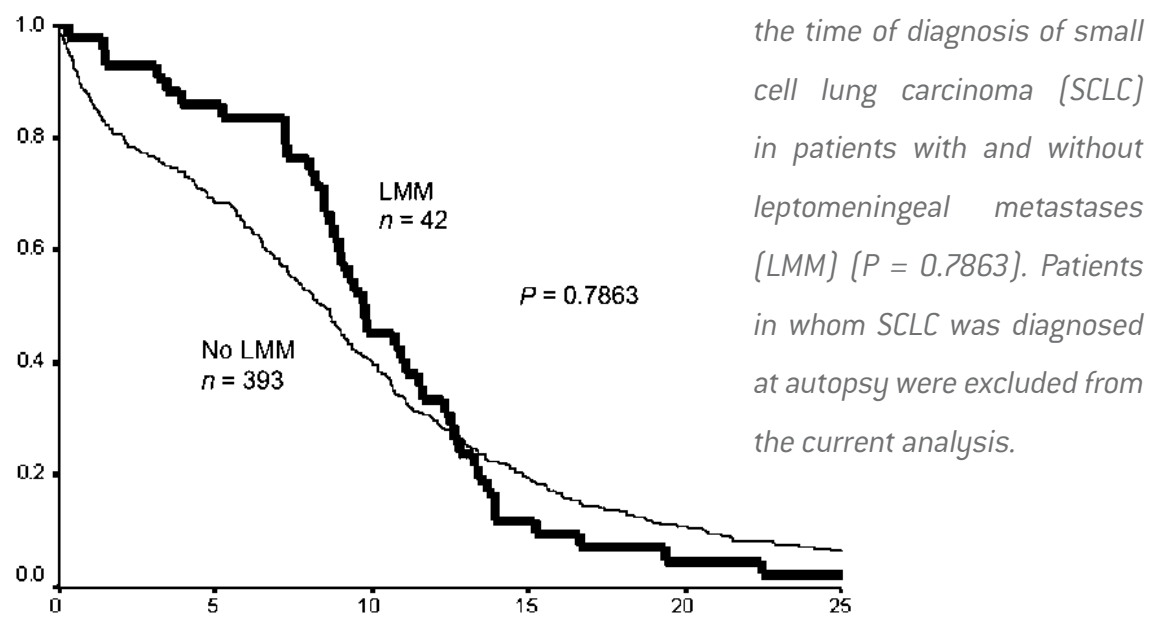

Survival time (mos)

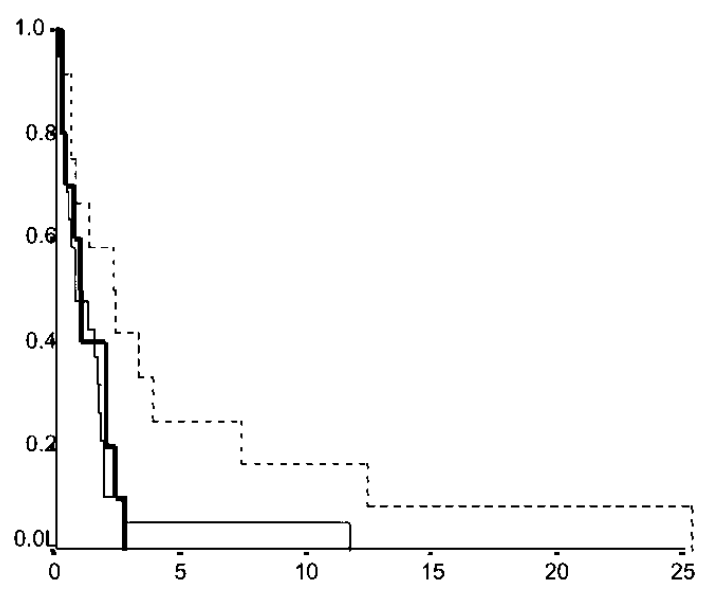

Figure 3. Kaplan-Meier curves showing the survival of patients with small cell lung carcinoma after the diagnosis of leptomeningeal metastases (LMM). Thick line: brain and spinal cord; dashed line: spinal cord; thin line: brain.

Survival time (mos) 
Twenty-one patients ( $47 \%$ ) had LMM located only in the leptomeninges surrounding the brain (cranial), 14 patients (31\%) had LMM located only in the leptomeninges surrounding the spinal cord (spinal), and the remaining 10 patients (22\%) had LMM diagnosed in both locations. The median survival times for these 3 groups were 0.7 months, 2.4 months, and 1.1 months, respectively. Figure 3 also shows that patients with LMM of the spinal cord survived longer than patients with cranial LMM. Approximately $71 \%$ of the patients with cranial LMM (22 of 31 patients) also were diagnosed with BM, whereas $50 \%$ of the patients with LMM of the spinal cord ( 7 of 14 patients) were found to have BM.

Twenty-two patients were not treated because of their poor clinical condition. Nine patients received local radiotherapy, five received systemic chemotherapy, and four patients received intrathecal chemotherapy. There was no significant difference noted in survival after the diagnosis of LMM between the treated and nontreated patients.

LMM-free survival 2 years after the diagnosis of SCLC was 78\% for patients without $\mathrm{BM}$ at the time of the diagnosis of SCLC and $61 \%$ for patients with BM at the time of the diagnosis of SCLC ( $P=0.05$, log-rank test $)$ (Fig. 4). BM were diagnosed in $67 \%$ of all patients with LMM ( 30 of 45 patients) ( Table 2). In 14 patients, BM were diagnosed earlier than LMM.

Figure 4. Kaplan-Meier curves showing the leptomeningeal metastases-free survival from the date of the diagnosis of small cell lung carcinoma (SCLC) in patients with and without brain metastases (BM).

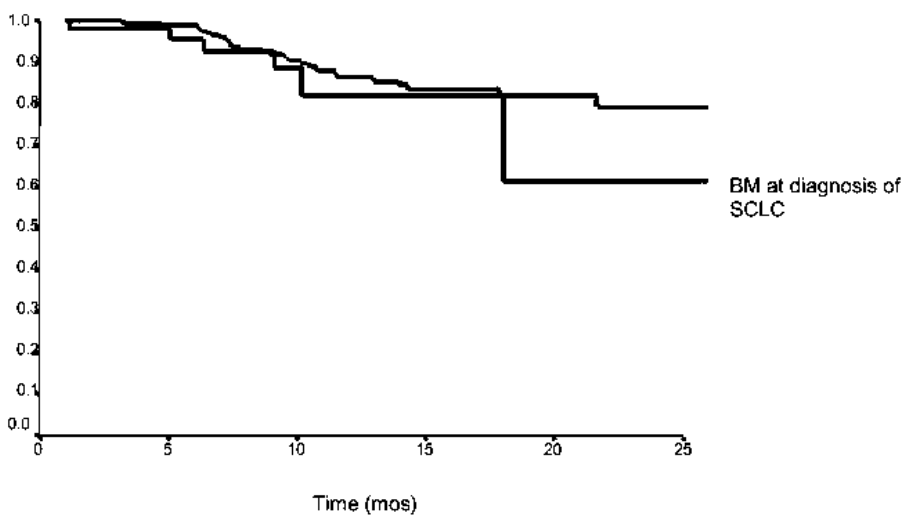


Figure 5. Risk of being diagnosed with leptomeningeal metastases (LMM) in patients with small cell lung carcinoma (SCLC) with brain metastases (BM). The numerator is the number of patients with LMM diagnosed after the diagnosis of BM was made. The denominator is all patients with $B M$.
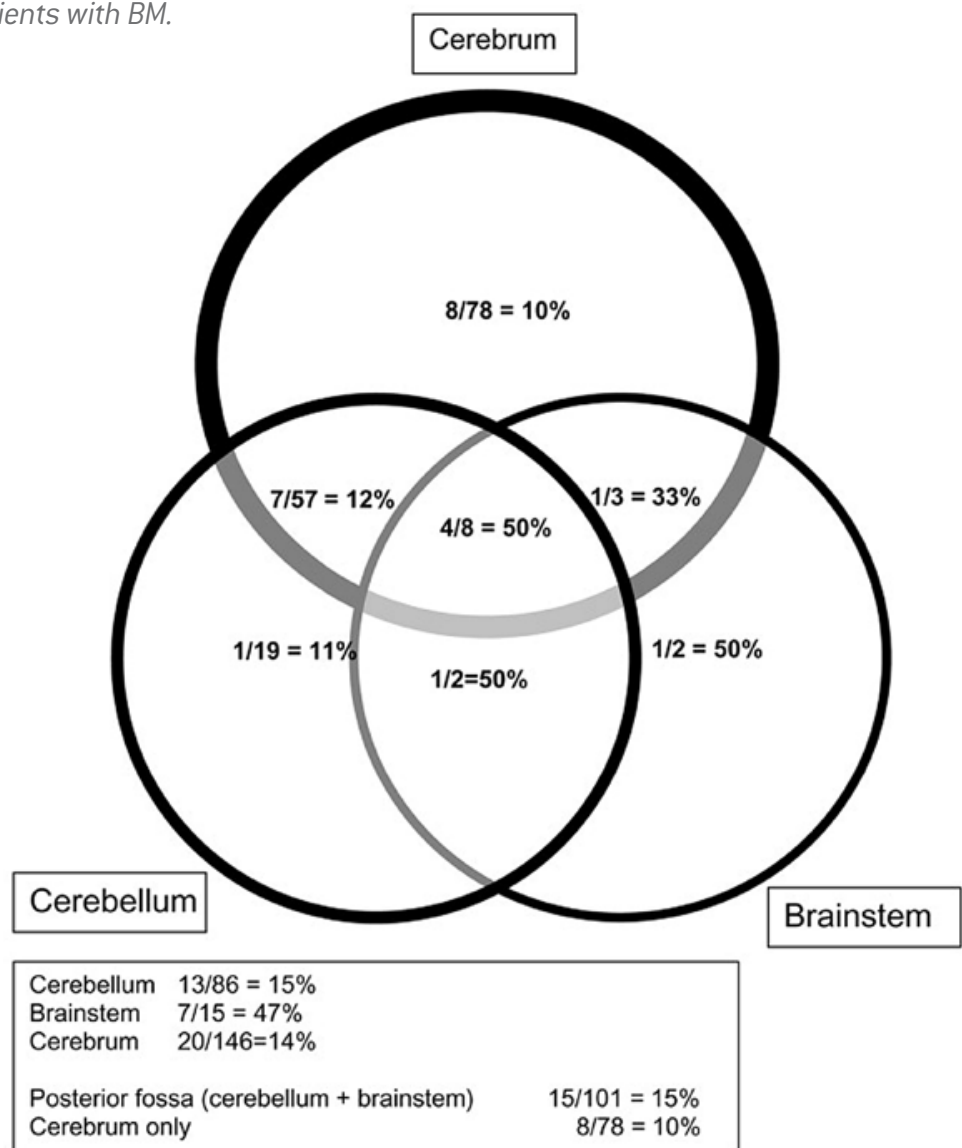

In nine patients, BM and LMM were diagnosed simultaneously, whereas in seven patients the BM were diagnosed after the diagnosis of LMM had been established.

Figure 5 shows the risk of being diagnosed with LMM in relation to the location of the BM. Patients with BM located in the posterior fossa were found to be at a higher risk (15\%) of developing LMM compared with patients with BM located in the cerebrum only $(10 \%)$. 


\section{Discussion}

The current study evaluated a patient group with LMM from SCLC. To our knowledge, this is the largest prospective study of LMM in one tumor type published to date. LMM were diagnosed through a combination of typical MRI findings and clinical symptoms and signs in nearly half the patients. Although the presence of malignant cells in the CSF is considered to be the gold standard, the above diagnostic tools also are widely accepted., ${ }^{2,714-17}$ We found that in $2 \%$ of the SCLC patients, LMM were present at the time of diagnosis. In our study population, the 1-year cumulative incidence was $10 \%$, which is in agreement with the findings of previous studies, although reported frequencies vary widely and the genuine incidence rates were not calculated in these studies..$^{1,4,10,18-20}$

The current study still may have underestimated the prevalence and incidence of LMM, for several reasons. First, despite the fact that we prospectively followed our patients and performed neurologic examinations and diagnostic examinations on a regular basis, we did not routinely obtain CSF, so we may have missed patients with asymptomatic LMM. Second, in patients already diagnosed with BM, symptoms and signs relating to the brain were attributed to these cerebral metastases. LMM were only searched for when the symptoms and signs involved more than one site of the neuroaxis. However, monofocal symptoms and signs do not rule out the possibility of coexistence with LMM. Third, an autopsy was performed in only $14 \%$ of the patients in the current study (66 of 458 patients]. If more autopsies had been performed, the incidence and prevalence figures for LMM might have been higher.

The median survival after the diagnosis of LMM from solid tumors is reported to be poor, with figures varying from 4-11 weeks in studies including different types of solid tumors. ${ }^{2,4,19,21-23}$ Rosen et al. ${ }^{10}$ reported a median survival of 7 weeks after the diagnosis of LMM in a population of SCLC patients. The current study findings regarding survival confirm those of these previous studies (Fig. 1). Patients who are diagnosed with LMM during followup appear to have a better survival rate during the first 8-9 months after the diagnosis of SCLC, as shown in Figure 2. Overall, however, there were no significant survival differences noted in the current study. Rosen et al. ${ }^{10}$ reported a similar survival rate. 
The results of the current study demonstrate that the location of the LMM influences survival (Fig. 3). Patients with LMM of the spinal cord were found to survive longer than patients with cranial LMM. BM were found to be diagnosed more often in patients with cranial LMM compared with patients with LMM of the spinal cord. Because BM are reported to have an adverse effect on survival, ${ }^{12}$ they may be a contributing factor to the poorer survival noted in the patients in the current study.

Previous studies have found that patients with CNS metastases in other sites of the neuroaxis at the time of diagnosis of SCLC were at a higher risk of developing LMM. ${ }^{10}$ The current study confirms this finding because the cumulative risk of developing LMM was found to be greater for those patients who had BM at the time of the diagnosis of SCLC. Furthermore, approximately two-thirds of the patients with LMM in the current study had been diagnosed with BM before the LMM were detected.

The pathogenesis of LMM is an ongoing topic of research. Several mechanisms to explain how malignant cells can reach the leptomeninges have been proposed. The cells could reach the leptomeninges by hematogenous or lymphatic dissemination, by growing around and along nerves and blood vessels, or by spreading from adjacent bone or brain parenchymal tumor deposits..$^{3,19-21,24,25}$ We hypothesized that if direct spreading of malignant cells from parenchymal tumors is a common route, patients with BM located in the posterior fossa would be at a higher risk of developing LMM than patients with BM located supratentorially. The findings of the current study support this hypothesis (Fig. 5). However, the incremental risk does not appear to be large. Unfortunately, the available data did not allow us to consider tumor load and the location of cerebral BM (proximity to leptomeninges), both of which may influence the development of LMM. In addition, cytology was not obtained in patients with BM located in the posterior fossa because lumbar puncture was contraindicated in these patients. Therefore, the incidence of LMM in patients with BM in the posterior fossa may have been underestimated. More studies, involving larger numbers of patients, will be needed to confirm these findings. 


\section{Conclusions}

The main conclusions to be drawn from the current study are as follows. 1] At the time of the diagnosis of SCLC, $2 \%$ of the patients were found to have LMM, whereas another $10 \%$ were diagnosed with LMM during the follow-up period. 2) LMM appear to have an adverse effect on survival. 3) SCLC patients with LMM of the spinal cord appear to survive longer than patients with cranial LMM. 4) SCLC patients with BM located in the posterior fossa appear to be at a higher risk of developing LMM than patients with cerebral BM. 


\section{References}

1 Balm M, Hammack J. Leptomeningeal carcinomatosis. Presenting features and prognostic factors. Arch Neurol. 1996; 53: 626-632.

2 Bokstein F, Lossos A, Siegal T. Leptomeningeal metastases from solid tumors: a comparison of two prospective series treated with and without intra-cerebrospinal fluid chemotherapy. Cancer. 1998; 82: 1756-1763.

3 Chamberlain MC. Leptomeningeal metastases: a review of evaluation and treatment. J Neurooncol. 1998; 37: 271-284.

4 Wasserstrom WR, Glass JP, Posner JB. Diagnosis and treatment of leptomeningeal metastases from solid tumors: experience with 90 patients. Cancer. 1982; 49: 759-772.

5 Bleyer WA, Byrne TN. Leptomeningeal cancer in leukemia and solid tumors. Curr Probl Cancer. 1988; 12: 181-238.

6 Sculier JP, Feld R, Evans WK, et al. Neurologic disorders in patients with small cell lung cancer. Cancer. 1987; 60: 2275-2283.

? Collie DA, Brush JP, Lammie GA, et al. Imaging features of leptomeningeal metastases. Clin Radiol. 1999; 54: 765-771.

8 Yap HY, Yap BS, Tashima CK, DiStefano A, Blumenschein GR. Meningeal carcinomatosis in breast cancer. Cancer. 1978; 42: 283-286.

9 Aroney RS, Dalley DN, Chan WK, Bell DR, Levi JA. Meningeal carcinomatosis in small cell carcinoma of the lung. Am J Med. 1981; 71: 26-32.

10 Rosen ST, Aisner J, Makuch RW, et al. Carcinomatous leptomeningitis in small cell lung cancer: a clinicopathologic review of the National Cancer Institute experience. Medicine (Baltimore). 1982; 61: 45-53.

11 Amer MH, Al-Sarraf M, Baker LH, Vaitkevicius VK. Malignant melanoma and central nervous system metastases: incidence, diagnosis, treatment and survival. Cancer. 1978; 42: 660 668.

12 Seute T, Leffers P, ten Velde GP, Twijnstra A. Neurologic disorders in 432 consecutive patients with small cell lung carcinoma. Cancer. 2004; 100: 801-806. 

carcinomatosis: the value interest of gadolinium-enhanced MRI. Neuroradiology. 1990; 32: 26-32. van der Ree TC, Dippel DW, Avezaat CJ, Sillevis Smitt PA, Vecht CJ, van den Bent MJ. Leptomeningeal metastasis after surgical resection of brain metastases. J Neurol Neurosurg Psychiatry. 1999; 66: 225-227. van Oostenbrugge RJ, Twijnstra A. Presenting features and value of diagnostic procedures in leptomeningeal metastases. Neurology. 1999; 53: 382-385. Freilich RJ, Krol G, DeAngelis LM. Neuroimaging and cerebrospinal fluid cytology in the diagnosis of leptomeningeal metastasis. Ann Neurol. 1995; 38: 51-5?.

18 Aisner J, Ostrow S, Govindan S, Wiernik PH. Leptomeningeal carcinomatosis in small cell carcinoma of the lung. Med Pediatr Oncol 1981; 9: 47-59. Jayson GC, Howell A. Carcinomatous meningitis in solid tumours. Ann Oncol. 1996; ?: ?73786. Grossman SA, Krabak MJ. Leptomeningeal carcinomatosis. Cancer Treat Rev. 1999; 25: $103-$ 119.

21 Gonzalez-Vitale JC, Garcia-Bunuel R. Meningeal carcinomatosis. Cancer. 1976; 37: 29062911.

22 Sagar SM. Carcinomatous meningitis: it does not have to be a death sentence. Oncology (Williston Park). 2002; 16: 237-243; discussion 244, 249-250.

23 Boogerd W, Hart AA, van der Sande JJ, Engelsman E. Meningeal carcinomatosis in breast cancer. Prognostic factors and influence of treatment. Cancer. 1991; 67: 1685-1695.

24 Nugent JL, Bunn PA Jr., Matthews MJ, et al. CNS metastases in small cell bronchogenic carcinoma: increasing frequency and changing pattern with lengthening survival. Cancer. 1979; 44: 1885-1893. Cancer. 1983; 51: 154-160. 



\begin{abstract}
4
Detection of brain metastases from Small Cell Lung Cancer; the consequences of changing imaging techniques (CT versus MRI)
\end{abstract}

Presented at the 59th annual meeting of the American Academy of Neurology, May 200?, Boston, USA

Tatjana Seute, Pieter Leffers, Guul P.M. ten Velde, Albert Twijnstra

Cancer 2007; accepted for publication 


\begin{abstract}
Purpose

The aims of this study were to show: (1) the effect of changing from computer tomography (CT) to magnetic resonance imaging (MRI) on the prevalence of detected brain metastases (BM) in patients with newly diagnosed Small Cell Lung Cancer (SCLC); (2) the difference in survival between patients with single and multiple BM; (3) the effect of the change in patient labeling on eligibility for prophylactic brain irradiation.
\end{abstract}

\title{
Patients and methods
}

From 1980 to 2004, 481 consecutive patients with SCLC were enrolled. Brain imaging was routinely performed after diagnosis of SCLC. At the start of 1991, MRI replaced $\mathrm{CT}$ in almost all patients. All patients were regularly examined by a neurologist.

\section{Results}

The prevalence of detected BM was $10 \%$ in the CT era and $24 \%$ in the MRI era. In the CT era, all detected BM were symptomatic, while in the MRI era, $11 \%$ were asymptomatic. In both periods, patients labeled as single BM survived longer than those labeled as multiple BM. For patients labeled as single BM or multiple BM, survival was longer in the MRI era than in the CT era. The proportion of patients who were eligible for prophylactic cranial irradiation was lower in the MRI era.

\section{Conclusions}

The estimated prevalence of BM increases when MRI is used instead of CT. Patients with detected single BM survive longer than patients with multiple BM. The apparently increased survival in the MRI era can be attributed to the 'Will Rogers phenomenon'. Using MRI makes fewer patients eligible for PCI. 


\section{Introduction}

Small Cell Lung Cancer (SCLC) represents a distinct clinical and pathological entity within the lung malignancies and presently accounts for approximately $13 \%$ of all lung cancer cases. ${ }^{1}$ It is the most aggressive pulmonary tumor, which leads to a poor survival. ${ }^{2}$ Dissemination to the brain is a frequently encountered complication of SCLC ${ }^{3,4}$ In the past three decades, estimates of the prevalence of brain metastases (BM) in SCLC patients have ranged from $10 \%$ to $18 \%$. 3 -?

In our hospital, computer tomography (CT) was used for the diagnosis of BM from SCLC until 1991. Thereafter we changed to the use of magnetic resonance imaging (MRI). MRI is a more sensitive diagnostic tool than CT for identifying BM. ${ }^{8-11}$ As a result, the number of patients with detected BM increases..$^{12}$ Furthermore, the ratio of patients with single and multiple BM changes. ${ }^{13}$ One study showed that a third of patients with a single BM on contrast-enhanced CT had multiple BM on gadolinium-enhanced MRI. ${ }^{10}$ In other words, CT fails to detect BM in an appreciable number of patients.

At present, enhanced MRI is considered to be the imaging technique of choice in patients suspected of BM. ${ }^{14,15}$ However, recent guidelines and current opinions concerning the treatment of BM are based on studies in which BM were detected through CT. ${ }^{16-18}$ It is debatable whether recommendations emanating from these studies are applicable to all patients with BM diagnosed through MRI.

This study was undertaken to investigate the influence of changing diagnostic techniques from CT to MRI on estimates of the prevalence of detected BM in SCLC patients. Additional research questions in this study were: (1) What is the influence of changing imaging technique from CT to MRI on the prevalence of detected single BM and how does this affect the prognosis of patients diagnosed with single BM? (2) How does changing the imaging technique from CT to MRI influence the eligibility for, and effectiveness of prophylactic cranial irradiation $(\mathrm{PCl})$ ? 


\section{Patients and methods}

\section{Patients}

From October 1980 to June 2004, 481 consecutive patients with microscopically and histologically proven SCLC were enrolled in the current study. Patients were diagnosed and treated at the University Hospital Maastricht (The Netherlands). Potential follow-up was at least one year. Patients were initially staged by a pulmonologist. Physical examination, routine blood and chemistry profile, chest X-ray, CT of the chest, and fiberoptic bronchoscopy were routinely performed. From 1991, MRI of the thoracal/lumbar spine and pelvis was included in the staging procedure. Limited disease (LD) was defined as tumor confined to one hemithorax, the mediastinum and the ipsilateral and/or supraclavicular lymph nodes. Tumor beyond these sites was defined as extensive disease (ED). All patients underwent diagnostic evaluation and treatment according to the standard protocol used in our hospital.

\section{Neurologic Follow-up}

All patients were examined by a neurologist at diagnosis of SCLC and every three months during the first year and every six months after one year. Imaging of the brain was performed at diagnosis of SCLC and after initial chemotherapy treatment. An additional brain scan was performed when patients had survived for 12 months after the diagnosis of SCLC. Up to and including 1990, contrast-enhanced CT scans were used (CT era). Thereafter (from 1991 until the end of the inclusion) MRI replaced CT (MRI era). However, in some cases with a high likelihood of BM and/or a need for immediate diagnosis, CT was used. CT was also performed for some claustrophobic patients. MRI scans [0.5 - $1.5 \mathrm{~T}$ system] were made before and after intravenous injection with the MR contrast medium gadolinium DTPA in a dose of $0.1 \mathrm{mmol} / \mathrm{kg}$. The first CT or MRI was performed within one month after diagnosis (within 2 weeks in $85 \%$ of the patients). In case of new neurological symptoms or signs, neurological consultations and diagnostics were performed more frequently. 


\section{Treatment}

Until 1999, all patients were initially treated with combination chemotherapy, consisting of cyclophosphamide $1000 \mathrm{mg} / \mathrm{m}^{2}$ and doxorubicin $45 \mathrm{mg} / \mathrm{m}^{2}$ on day 1 and etoposide $100 \mathrm{mg} / \mathrm{m}^{2}$ on days 1,3 and 5 , repeated every three weeks, with a maximum of five cycles. From 2000, all LD patients received carboplatin AUC 5 on day 1 and etoposide $120 \mathrm{mg} / \mathrm{m}^{2}$ on day 1,2 and 3. Patients received $8 \mathrm{mg}$ dexamethason at the start of each cycle as anti-emetic treatment. Local radiotherapy to the chest was occasionally applied to the primary tumor site after chemotherapy; no strict criteria were established for this treatment till 1995. Thereafter all LD patients received loco-regional radiotherapy after a partial or complete response to chemotherapy. From 2000, LD patients with a WHO performance score ${ }^{19}$ of $0-1$ were treated with concomitant chemo-radiotherapy and LD patients with a WHO performance score of $2-3$ were treated with sequential chemo-radiotherapy. Response after initial treatment was assessed using standard criteria.20 Complete remission $(C R)$ was defined as a total clinical and radiological resolution of the disease. A reduction of at least $50 \%$ of all measurable lesions was regarded as partial remission (PR), and the remainder of the responses was regarded as no response.

Table 1. Patient characteristics

\begin{tabular}{|l|c|c|c|c|}
\hline Characteristics & CT era $(\mathrm{n}=217)$ & $\%$ & MRI era $(\mathrm{n}=264)$ & $\%$ \\
\hline Median age (range) & 66 years $(42-99)$ & & 67 years (32-91) & \\
\hline Male gender & 184 & 85 & 192 & 73 \\
\hline Extensive disease & 140 & 65 & 190 & 72 \\
\hline Liver metastases & 75 & 35 & 87 & 33 \\
\hline Bone metastases & 51 & 24 & 109 & 41 \\
\hline Other & 67 & 31 & 76 & 29 \\
\hline Leptomeningeal metastases & 1 & 1 & 8 & 3 \\
\hline
\end{tabular}


Clinically manifest BM were treated with WBRT with fractions of 3 Gy given five times a week up to a total dose of $30 \mathrm{~Gy}$. In the case of cerebral edema, patients received corticosteroid medication.

Patients in CR after initial chemotherapy were eligible for prophylactic cranial irradiation (PCI). Until 1986, both patients with LD and ED could opt for PCI. After 1986, only patients with LD could do so. Between 1990 and 1997, PCI was excluded from the treatment protocol. $\mathrm{PCl}$ was administered to the entire brain after the completion of the chemotherapy. The total dose was $30 \mathrm{~Gy}$, administered as either $3 \mathrm{~Gy}$ given 4 times a week or 2 Gy given 5 times a week.

\section{Statistical methods}

Survival curves and hazard ratios were based on multivariable Cox-regression. The proportional hazard assumption was checked through visual inspection of log-log plots. All analyses were carried out with SPSS 11.0 for Windows (SPSS Inc, Chicago IL).

\section{Results}

The patient characteristics of the 481 included patients are shown in table 1. Up to and including 1990 (= CT era), 217 patients were enrolled. The remaining 264 patients were included from 1991 until 2004 (= MRI era). The percentage of female patients increased by $12 \%$ during the MRI era, which is probably related to the increased prevalence of smoking among women.1 More patients were classified as having ED during the MRI era compared to the CT era, due to increased sensitivity of the diagnostic tools and the addition of the MRI of the spine and pelvis to the staging procedure after 1991. The latter is also responsible for the noteworthy increase in the percentage of patients with detected bone metastases (from $24 \%$ to $41 \%$ ). The median survival time after the diagnosis of SCLC was 8.6 months (range 0 - 157.1 months) for patients diagnosed in the CT era. Patients diagnosed since 1991 (MRI era) had a similar median survival time of 8.7 months (range $0-48.3$ months). 
Table 2. Detected brain metastases in CT era

\begin{tabular}{|l|c|c|c|c|}
\hline $\begin{array}{l}\text { Diagnostic tool used } \\
\text { at diagnosis of SCLC }\end{array}$ & $\begin{array}{c}\text { Number } \\
\text { of patients }\end{array}$ & $\begin{array}{c}\text { Symptomatic } \\
\text { BM }\end{array}$ & $\begin{array}{c}\text { Asymptomatic } \\
\text { BM }\end{array}$ & $\begin{array}{c}\text { BM } \\
\text { autopsy* }\end{array}$ \\
\hline CT & 160 & $16(10 \%)$ & 0 & - \\
\hline MRI & 1 & 0 & 0 & - \\
\hline No scan, autopsy & 15 & - & - & 8 \\
\hline No scan, no autopsy & 33 & $?$ & $?$ & - \\
\hline Missing data & 8 & $?$ & $?$ & - \\
\hline Total & 217 & 16 & 0 & 8 \\
\hline
\end{tabular}

\section{Brain metastases detected in MRI era}

\begin{tabular}{|c|c|c|c|c|c|c|}
\hline \multirow{2}{*}{$\begin{array}{l}\text { Diagnostic tool used } \\
\text { at diagnosis of SCLC } \\
\text { CT }\end{array}$} & \multirow{2}{*}{$\begin{array}{c}\begin{array}{c}\text { Number } \\
\text { of patients }\end{array} \\
40\end{array}$} & \multicolumn{2}{|c|}{ Symptomatic BM } & \multicolumn{2}{|c|}{$\begin{array}{c}\text { Asymptomatic } \\
\text { BM }\end{array}$} & \multirow{2}{*}{$\frac{\begin{array}{c}\text { BM } \\
\text { autopsy* }\end{array}}{-}$} \\
\hline & & 16 & \multirow{2}{*}{$(13 \%)$} & 0 & \multirow{2}{*}{$(11 \%)$} & \\
\hline MRI & 191 & 14 & & 25 & & - \\
\hline No scan, autopsy & 20 & \multicolumn{2}{|c|}{ - } & \multicolumn{2}{|c|}{ - } & 3 \\
\hline No scan, no autopsy & 11 & \multicolumn{2}{|c|}{ ? } & \multicolumn{2}{|c|}{$?$} & - \\
\hline Missing data & 2 & \multicolumn{2}{|c|}{ ? } & \multicolumn{2}{|c|}{ ? } & - \\
\hline Total & 264 & \multicolumn{2}{|c|}{30} & \multicolumn{2}{|c|}{25} & 3 \\
\hline
\end{tabular}

* BM diagnosed at autopsy

BM diagnosed within four weeks after the diagnosis of SCLC were considered to be synchronous (present at the time of diagnosis of SCLC). Table 2 shows that the number of patients diagnosed with BM increased considerably during the era in which MRI was used instead of CT. Synchronous BM were detected in 10\% (16/160) of the patients undergoing imaging of the brain in the CT era. These patients all had clinical signs that could be attributed to the BM (symptomatic BM). In 48 patients, no CT scan was performed because of poor clinical condition or early death. Fifteen of these patients, however, underwent 
autopsy, with BM being found in eight patients (53\%). During the MRI era, 40 patients underwent a CT of the brain (table 2). Synchronous symptomatic BM were detected in $13 \%$ (30/231) of the patients who underwent imaging of the brain during the MRI era. In addition, BM without clinical symptoms or signs (asymptomatic BM) were detected by MRI in $11 \%$ (25/231). The total estimated prevalence of BM detected in the MRI era was $24 \%$ (55/231). During the MRI era, 31 patients did not undergo a brain scan because of poor clinical condition or early death. Twenty of these patients underwent autopsy, BM being found in three patients (15\%).

Within the group of patients diagnosed with $\mathrm{BM}$, we distinguished between single and multiple BM. In the $\mathrm{CT}$ era, synchronous single $\mathrm{BM}$ were detected in $6 \%$ ( $95 \% \mathrm{Cl}, 3 \%$ to $10 \%$ ) of the patients who underwent CT, compared to $10 \%$ ( $95 \% \mathrm{Cl}, 6 \%$ to $14 \%$ ) of the patients who underwent imaging of the brain in the MRI era (table 3). The difference between the two eras in the percentage of multiple BM detected was even larger: $14 \%$ ( $95 \% \mathrm{CI}, 10 \%$ tot $19 \%$ ) versus $4 \%$ ( $95 \% \mathrm{Cl}, 2 \%$ to $9 \%$ ). Hence, the estimated prevalences of both single and multiple BM were higher in the MRI era. It was remarkable that $73 \%$ of the patients with single BM were older than 70 years, compared to $24 \%$ of the patients with multiple BM.

Table 3. Detected single and multiple brain metastases at diagnosis of SCLC

\begin{tabular}{|c|c|c|c|c|}
\hline Era & $\begin{array}{l}\text { Diagnostic tool used } \\
\text { at diagnosis of SCLC }\end{array}$ & $\begin{array}{l}\text { Number of patients } \\
\text { who underwent imaging }\end{array}$ & $\begin{array}{c}\text { Single } \\
B M\end{array}$ & $\begin{array}{l}\text { Multiple } \\
\text { BM }\end{array}$ \\
\hline CT era & CT & 160 & $9(6 \%)$ & $7(4 \%)$ \\
\hline \multirow[t]{4}{*}{ MRI era } & CT & 40 & 7 & 9 \\
\hline & MRI & 191 & 15 & 24 \\
\hline & & 231 & $22(10 \%)$ & $33(14 \%)$ \\
\hline & Total & 391 & 31 & 40 \\
\hline
\end{tabular}


Multivariable Cox-regression to analyze the influence of the number of BM was stratified for era (CT vs. MRI) and included sex and age $(\leq \mathrm{PO}$ Vs $>70)$ as co-variables. Figure 1 shows the differences in survival times between patients with single and multiple BM in both the CT era and the MRI era. To make the comparison between the era's valid the survival curves were calculated for a population in which $77 \%$ was male and $31 \%$ was older than 70 . Figure $1 \mathrm{a}$ refers to patients who all underwent $\mathrm{CT}$, while figure $1 \mathrm{~b}$ refers to patients who had CT or MRI in the MRI era. The hazard ratio for detected multiple versus single BM was $4.0(p=0.09 ; 95 \% \mathrm{Cl}=0.8-19.6)$ in the $\mathrm{CT}$ era and $2.8(\mathrm{p}=0.004 ; 85 \% \mathrm{Cl}: 1.4-5.7)$ in the MRI era. This means that patients detected with multiple BM have approximately a 3.5 times higher risk of dying compared to patients with single BM.

\section{Figure 1.}
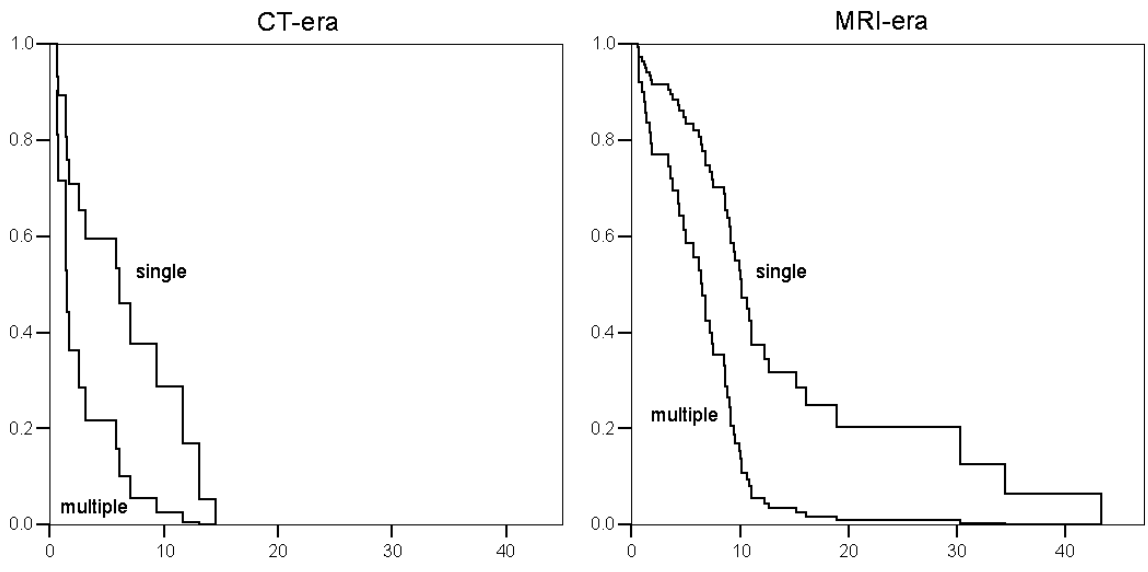

survival time (months) 


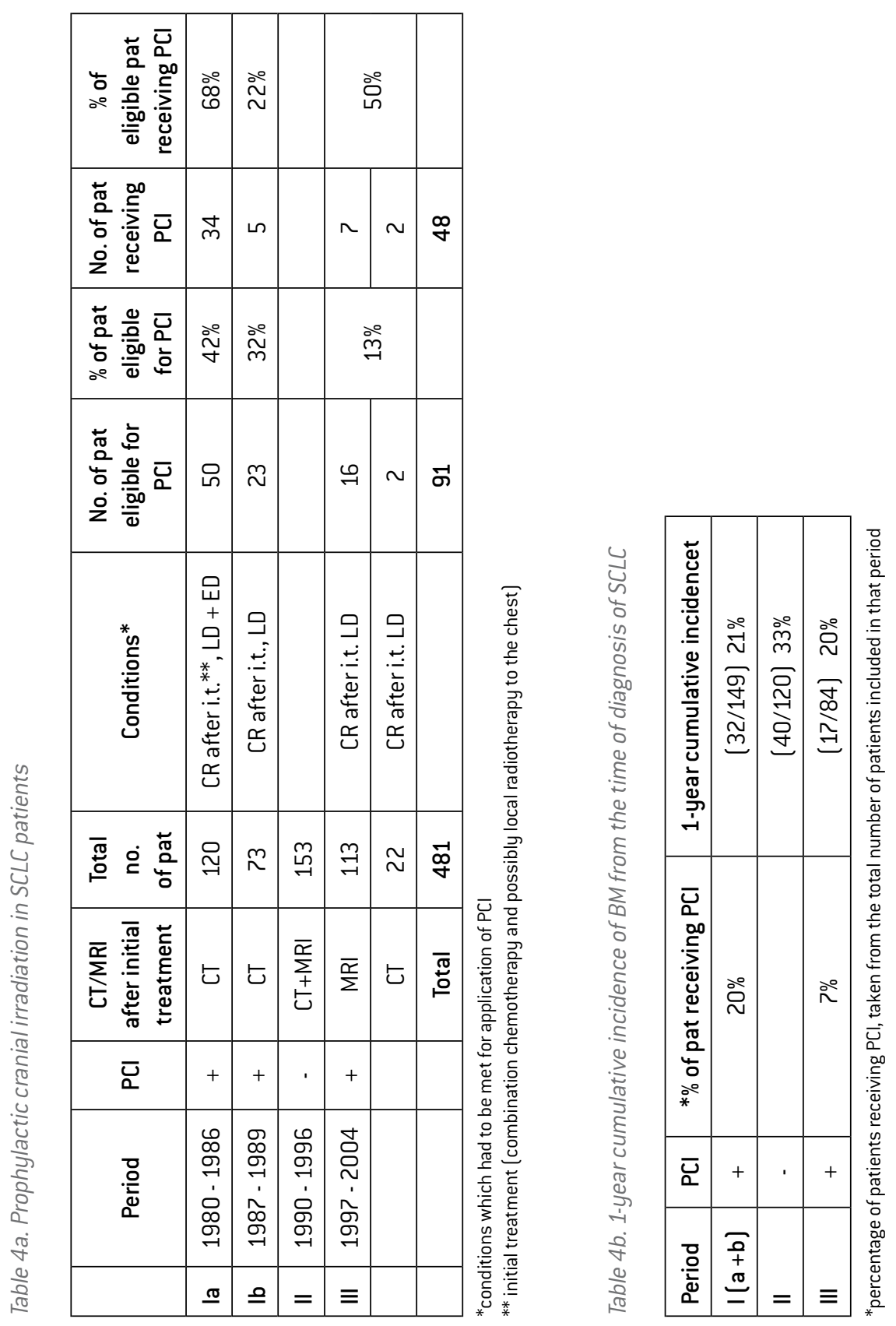


In the MRI era both survival curves were shifted to the right when compared to the CT era. This seeming improvement of survival may be explained by the so-called 'Will Rogers Phenomenon', which will be explained in the discussion section.

During the inclusion, three different treatment protocols were used as regards $\mathrm{PCl}$ (table 4a). During periods la and Ib (CT era), 42\% (50/120) and 32\% (23/73) of the patients, respectively, were eligible for $\mathrm{PCl}$ (meaning LD + CR after chemotherapy and no BM). During period III (MRI era), the percentage of eligible patients was only 13 (18/135). The decreasing proportion of eligible patients is explained by the fact that during period III more sensitive diagnostic tools were used to stage and evaluate the patients. This led to a lower number of patients staged as LD and a lower number of patients having CR after initial treatment. During period III, BM were mainly detected using MRI, but two patients who were deemed eligible for $\mathrm{PCl}$ had a CT scan. The percentage of eligible patients who actually underwent $\mathrm{PCI}$ differed between period I and III. In period Ib, only $22 \%$ (5/23) received $\mathrm{PCl}$. This low percentage was caused by the fact that at that time, $\mathrm{PCl}$ was considered to have negative effects on cognition. Treating physicians therefore dissuaded patients from having PCI. It was eventually excluded from the treatment protocol from 1990 until 199?.22 Around that time, other studies reported a measurable deficit in neurocognitive function prior to $\mathrm{PCl}$, which did not worsen further after $\mathrm{PCl} .^{23,24}$ From $1997 \mathrm{PCl}$ was reinstated in the treatment protocol. During period III, 50\% (9/18) of the eligible patients actually underwent $\mathrm{PCl}$. In this period, many patients refused brain irradiation for fear of side effects. In total, $20 \%$ (39/193) of all patients received PCl during periods la and $\mathrm{lb}$, compared to $7 \%$ (9/135) in period III (table 4b). The 1-year cumulative incidence of BM during periods I ( $\mathrm{a}$ and $\mathrm{b}$ combined) and III was almost the same ( $21 \%$ and $20 \%$, respectively; table $4 \mathrm{~b}$ ). In the period in which PCI was not applied (II), the 1-year cumulative incidence was 33\%. During period III, 18 patients were eligible for $\mathrm{PCl}$. In four of these patients, BM were diagnosed within one year. The median survival of these nine patients who did not receive $\mathrm{PCl}$ was 13 months (range 8.0 - 32.4), compared to a median survival of 24 months (range $6.4-41.4$ ) in the patient group who underwent $\mathrm{PCl}$. None of the nine patients who underwent $\mathrm{PCl}$ were diagnosed with BM during follow-up. 


\section{Discussion}

The value of gadolinium-enhanced MRI versus contrast-enhanced CT for the diagnosis of BM from solid tumors has been the subject of several studies. ${ }^{25-27}$ From these studies, it was concluded that MRI is 'superior' to CT, meaning that MRI is a more sensitive technique to detect BM. The effect using MRI on the estimated prevalence of detected BM in SCLC patients had not been investigated. Furthermore, the effect of using MRI on the eligibility for and application of $\mathrm{PCl}$ was unclear. In the present study we were able to address these issues, since during the inclusion period CT and MRI were successively used for the detection of BM.

The estimated prevalence of symptomatic BM was $10 \%$ in the CT era. In the MRI era, the estimated prevalence of BM increased to $24 \%$ (table 2). This rise was for the greater part caused by the detection of asymptomatic BM through MRI in 25 patients (11\%), though slightly more symptomatic BM were also detected (3\%). Since a substantial number of patients underwent CT instead of the more sensitive MRI, this may even be an underestimate. The proportions of patients in whom single BM were detected increased by $4 \%$ in the MRI era, while the proportion of patients with multiple BM increased by $10 \%$. From these findings, we conclude that a part of the patients without BM on CT does have single or multiple BM on MRI and that a part of the patients with single BM diagnosed through CT have multiple BM on MRI (figure 2). Figure 2 shows that one individual patient will be allocated to different categories depending on the type of scan. In other words, labeling a patient as having no BM, single BM or multiple BM is largely dependent on the diagnostic tool that is used to establish the diagnosis of BM. Since patients in our study did not undergo both MRI and CT, we do not know which patients migrated to a different category.

In most solid tumors, the number of BM (single or multiple) is of prognostic significance and influences the choice of treatment of BM. ${ }^{14,28-30}$ In SCLC patients it is assumed that multiple sub-clinical metastases are already present in the brain at the time of the diagnosis of SCLC, so the number of BM is not considered to be of prognostic significance. ${ }^{31}$ However our Cox regression survival analysis (figure 1), shows that in both the CT era and 
CT era

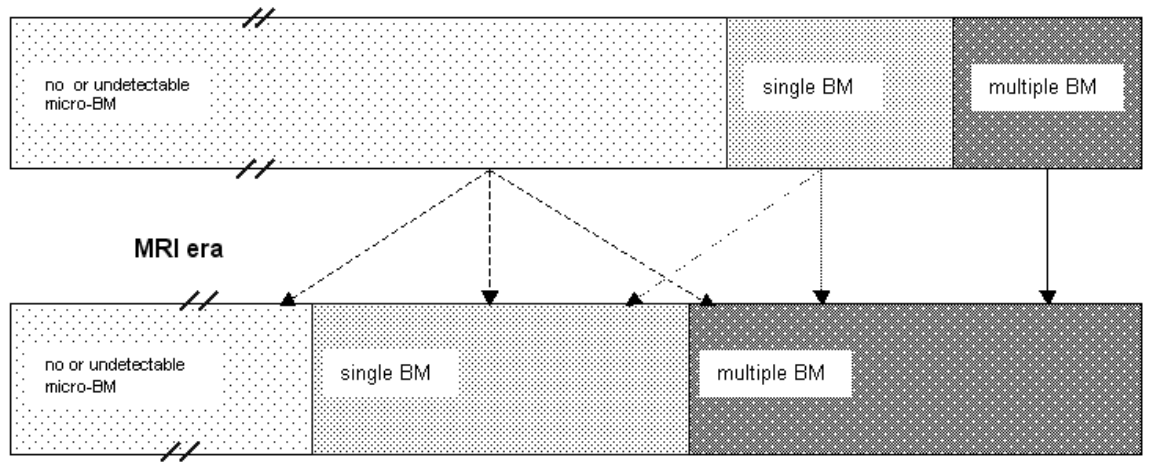

the MRI era, patients with single synchronous BM had a longer estimated survival than patients with multiple BM.

In the MRI era ( figure 1) the survival curves of both patients with single and multiple BM have shifted to the right compared to the curves in the CT era (figure 1). Nevertheless, the prognosis for the total group of patients was equally long in the MRI era. This paradox is called the Will Rogers phenomenon or stage migration ${ }^{32}$ : A proportion of the BM detected through MRI would formerly (in the CT era) have been unidentified. Patients who previously would have been classified in the group without BM ['good stage'] were now assigned to the group with BM ['bad stage'] [figure 2). Because the prognosis for those who migrated, although worse than that for other members of the good-stage group, was better than that for other members of the bad-stage group, survival rates rose in each group without any change in individual outcomes.

The favorable effect of PCI in LD SCLC patients with CR after initial chemotherapy has been demonstrated in several trials in which CT was used to detect BM. ${ }^{33-36} \mathrm{PCl}$ is part of the standard treatment protocol for SCLC patients. ${ }^{16}$ However, over the past 25 years, the diagnostic tools used to stage and evaluate SCLC patients have evolved. In this study 
we were able to show how this has led to changes concerning the application of $\mathrm{PCl}$ in our patient group (table 4a). The most striking finding is the decreased percentage of patients eligible for $\mathrm{PCl}$. But despite the fact that fewer patients received $\mathrm{PCl}$, the one-year cumulative incidence of BM was almost equal (21\% and $20 \%$ ) in the two periods when $\mathrm{PCl}$ was applied (table $4 \mathrm{~b}$ ), compared to $33 \%$ in the period when $\mathrm{PCl}$ was not applied. We speculate that in period I patients underwent PCI who would have had BM on MRI. In other words, the diagnostic tool used to detect BM plays an important role in the selection of patients eligible for $\mathrm{PCl}$. We therefore argue that results of the earlier studies into $\mathrm{PCl}$ cannot be extrapolated to the current situation, in which MRI is mostly used to detect BM.

\section{Conclusions}

The main conclusions to be drawn from this study are as follows.

1) The estimated prevalence of detected $B M$ increased from $10 \%$ to $24 \%$ in the period when MRI was used in the majority of patients instead of CT to establish the diagnosis of BM. This difference was caused predominantly by the detection of asymptomatic BM through MRI.

2) Patients with single BM survive longer than patients with multiple BM.

3) $\mathrm{PCl}$ reduced the one-year cumulative incidence of $\mathrm{BM}$ by $12 \%$ and $13 \%$ in the $\mathrm{CT}$ era and the MRI era, respectively. The number of patients eligible for PCl decreases when more sensitive diagnostic tools are used. 


\section{References}

1. Govindan R, Page N, Morgensztern D, et al: Changing epidemiology of small-cell lung cancer in the United States over the last 30 years: analysis of the surveillance, epidemiologic, and end results database. J Clin Oncol 24:4539-44, 2006

2. Jackman DM, Johnson BE: Small-cell lung cancer. Lancet 366:1385-96, 2005

3. Seute T, Leffers P, ten Velde GP, et al: Neurologic disorders in 432 consecutive patients with small cell lung carcinoma. Cancer 100:801-6, 2004

4. van Oosterhout AG, van de Pol M, ten Velde GP, et al: Neurologic disorders in 203 consecutive patients with small cell lung cancer. Results of a longitudinal study. Cancer 77:1434-41, 1996

5. Newman SJ, Hansen HH: Proceedings: Frequency, diagnosis, and treatment of brain metas tases in 247 consecutive patients with bronchogenic carcinoma. Cancer 33:492-6, 1974

6. Nugent JL, Bunn PA, Jr., Matthews MJ, et al: CNS metastases in small cell bronchogenic carcinoma: increasing frequency and changing pattern with lengthening survival. Cancer 44:1885-93, 1979

7. Sculier JP, Feld R, Evans WK, et al: Neurologic disorders in patients with small cell lung cancer. Cancer 60:2275-83, 1987

8. Davis PC, Hudgins PA, Peterman SB, et al: Diagnosis of cerebral metastases: double-dose delayed CT vs contrast-enhanced MR imaging. AJNR Am J Neuroradiol 12:293-300, 1991

9. Suzuki K, Yamamoto M, Hasegawa Y, et al: Magnetic resonance imaging and computed tomography in the diagnoses of brain metastases of lung cancer. Lung Cancer 46:357-60, 2004

10. Schellinger PD, Meinck HM, Thron A: Diagnostic accuracy of MRI compared to CCT in patients with brain metastases. J Neurooncol 44:275-81, 1999

11. Akeson P, Larsson EM, Kristoffersen DT, et al: Brain metastases--comparison of gadodiamide injection-enhanced MR imaging at standard and high dose, contrast-enhanced CT and noncontrast-enhanced MR imaging, 1995

12. Hochstenbag MM, Twijnstra A, Wilmink JT, et al: Asymptomatic brain metastases (BM) in 
small cell lung cancer (SCLC): MR- imaging is useful at initial diagnosis. J Neurooncol 48:243-8., 2000

13. Sze G, Milano E, Johnson C, et al: Detection of brain metastases: comparison of contrastenhanced MR with unenhanced MR and enhanced CT. AJNR Am J Neuroradiol 11:785-91, 1990

14. Davey P: Brain metastases: treatment options to improve outcomes. CNS Drugs 16:325-38, 2002

15. Kaal EC, Taphoorn MJ, Vecht CJ: Symptomatic management and imaging of brain metastases. J Neurooncol 75:15-20, 2005

16. Soffietti R, Cornu P, Delattre JY, et al: EFNS Guidelines on diagnosis and treatment of brain metastases: report of an EFNS Task Force. Eur J Neurol 13:674-81, 2006

17. Soffietti R, Costanza A, Laguzzi E, et al: Radiotherapy and chemotherapy of brain metastases. J Neurooncol 75:31-42, 2005

18. Kaal EC, Niel CG, Vecht CJ: Therapeutic management of brain metastasis. Lancet Neurol 4:289-98, 2005

19. Oken MM, Creech RH, Tormey DC, et al: Toxicity and response criteria of the Eastern Cooperative Oncology Group. Am J Clin Oncol 5:649-55, 1982

20. Macdonald DR, Cascino TL, Schold SC, Jr., et al: Response criteria for phase II studies of supratentorial malignant glioma. J Clin Oncol 8:1277-80, 1990

21. Paesmans M, Sculier JP, Lecomte J, et al: Prognostic factors for patients with small cell lung carcinoma: analysis of a series of 763 patients included in 4 consecutive prospective trials with a minimum follow-up of 5 years. Cancer 89:523-33, 2000

22. Fleck JF, Einhorn LH, Lauer RC, et al: Is prophylactic cranial irradiation indicated in small-cell lung cancer? J Clin Oncol 8:209-14, 1990

23. Van Oosterhout AG, Boon PJ, Houx PJ, et al: Follow-up of cognitive functioning in patients with small cell lung cancer. Int J Radiat Oncol Biol Phys 31:911-4., 1995

24. Komaki R, Meyers CA, Shin DM, et al: Evaluation of cognitive function in patients with limited small cell lung cancer prior to and shortly following prophylactic cranial irradiation. Int J Radiat Oncol Biol Phys 33:179-82, 1995 
25. Sze G, Stimac GK, Bartlett C, et al: Multicenter study of gadopentetate dimeglumine as an MR contrast agent: evaluation in patients with spinal tumors. AJNR Am J Neuroradiol 11:967-74,1990

26. Mastronardi L, Lunardi P, Puzzilli F, et al: The role of MRI in the surgical selection of cerebral metastases. Zentralbl Neurochir 60:141-5, 1999

27. Yokoi K, Kamiya N, Matsuguma $\mathrm{H}$, et al: Detection of brain metastasis in potentially operable non-small cell lung cancer: a comparison of CT and MRI. Chest 115:714-9, 1999

28. Gaspar L, Scott C, Rotman M, et al: Recursive partitioning analysis (RPA) of prognostic factors in three Radiation Therapy Oncology Group (RTOG) brain metastases trials. Int J Radiat Oncol Biol Phys 37:745-51, 1997

29. Lagerwaard FJ, Levendag PC, Nowak PJ, et al: Identification of prognostic factors in patients with brain metastases: a review of 1292 patients. Int J Radiat Oncol Biol Phys 43:795-803, 1999

30. Andrews DW, Scott CB, Sperduto PW, et al: Whole brain radiation therapy with or without stereotactic radiosurgery boost for patients with one to three brain metastases: phase III results of the RTOG 9508 randomised trial. Lancet 363:1665-72, 2004

31. Mehta MP: Models support prophylactic cranial irradiation. J Clin Oncol 24:3524-6, 2006

32. Feinstein AR, Sosin DM, Wells CK: The Will Rogers phenomenon. Stage migration and new diagnostic techniques as a source of misleading statistics for survival in cancer. $\mathrm{N} \mathrm{Engl} \mathrm{J}$ Med 312:1604-8, 1985

33. Arriagada R, Le Chevalier T, Riviere A, et al: Patterns of failure after prophylactic cranial irradiation in small- cell lung cancer: analysis of 505 randomized patients. Ann Oncol 13:74854., 2002

34. Auperin A, Arriagada R, Pignon JP, et al: Prophylactic cranial irradiation for patients with small-cell lung cancer in complete remission. Prophylactic Cranial Irradiation Overview Collaborative Group. N Engl J Med 341:476-84, 1999

35. Yang GY, Matthews RH: Prophylactic cranial irradiation in small-cell lung cancer. Oncologist 5:293-8, 2000

36. Lee JJ, Bekele BN, Zhou X, et al: Decision analysis for prophylactic cranial irradiation for patients with small-cell lung cancer. J Clin Oncol 24:3597-603, 2006 



\begin{abstract}
5
First-line systemic chemotherapy for synchronous brain metastases from Small Cell Lung Cancer: A systematic review
\end{abstract}

Tatjana Seute, Albert Twijnstra, Pieter Leffers 


\section{Abstract}

The aim of this review is to assess the effect of first-line systemic chemotherapy on synchronous brain metastases (BM) in Small Cell Lung Cancer patients. Effectiveness will be evaluated based upon the radiological response (local brain response) and the progression free survival time.

\section{Background}

Small Cell Lung Cancer (SCLC) is frequently complicated by BM. At the time of diagnosis at least $18 \%$ of the patients have symptomatic or asymptomatic BM. ${ }^{1}$ The aims of treatment of BM from SCLC are to reduce symptoms and to prevent complications, such as neurologic deficits and cognitive impairment. Traditionally the standard treatment for symptomatic BM is whole brain radiotherapy (WBRT), with reported response rates (complete response or partial response) ranging from $56 \%-92 \%{ }^{2-4}$

For a long time systemic chemotherapy was not considered an effective for treatment of BM, since it was assumed that the brain was a pharmacological sanctuary where metastases were protected from cytotoxic drugs by the blood brain barrier (BBB). However, in recent decades, it has become clear that the BBB is disrupted in metastatic tumor tissue. ${ }^{5-8}$ Since then, the effectiveness of first-line and second-line systemic chemotherapy for the treatment of BM from SCLC has been the topic of several studies. ${ }^{3,9-12}$ Several authors claimed that synchronous BM from SCLC and other solid tumors, have a response rate $(R R)$ to systemic chemotherapy that is similar to the RR for the primary tumor., ${ }^{3,10,11}$ It has been suggested that BM from SCLC should initially be treated with systemic chemotherapy only. ${ }^{13}$ The debate about whether WBRT should be part of the initial treatment is still ongoing. ${ }^{9,14}$

The aim of the present review is to investigate whether there is any evidence that can clarify the role of systemic chemotherapy in the treatment of synchronous BM from SCLC. 


\section{Objectives}

To assess whether first-line systemic chemotherapy is effective to treat synchronous BM in patients with SCLC. Effectiveness will be measured based upon radiological response of BM (local brain response) and progression free survival time.

\section{Criteria for considering studies for this review}

\section{Types of studies}

- Randomized controlled trials (RCTs) or clinical controlled trials (CCTs): first-line chemotherapy versus placebo, reporting about the effect on brain metastases

- Randomized controlled trials or clinical controlled trials: first-line chemotherapy A versus first-line chemotherapy $B$, reporting about the effect on brain metastases Since beforehand we were somewhat familiar with the literature we expected the number of available RCTs to be low. Therefore we decided to also discuss other types of studies, although these studies were not formally included in the review:

- Observational studies concerning first-line chemotherapy for SCLC reporting about the effect on brain metastases

- Case series concerning first-line chemotherapy for SCLC reporting about the effect on brain metastases

\section{Types of participants}

Patients with histologically or cytologically proven SCLC in whom synchronous BM were found on either computer tomography (CT) scan or magnetic resonance imaging (MRI) will be included. BM had to be diagnosed within 4 weeks after the diagnosis of SCLC.

\section{Types of interventions}

First-line systemic chemotherapy 


\section{Types of outcome measures}

- Radiological response of BM / local brain response. The radiological response will be determined as the percentage of patients achieving complete remission (CR) or partial remission (PR). CR is defined as the complete disappearance of all tumor lesions on MRI. PR was defined as at least $50 \%$ decrease of total tumor size of the lesions that had been measured, without the appearance of any new lesions or progression of any lesions on CT or MRI.15

- Progression free survival time. Progression free survival time is defined as the time from randomization until or inclusion in the study progressive brain disease (enlarging brain metastases and/or new brain metastases based on CT or MRI).

\section{Search strategy for identification of studies}

\section{A. Electronic Databases}

A search for identification of studies on the review topic was undertaken of the following databases: MEDLINE from 1966- 2006, and The Cochrane Library 2006, Issue 4. The following search strategies were applied:

MEDLINE:

1 (brain[tiab] OR cerebral[tiab]) AND neoplasm metastasis[mh]

2 (brain[tiab] OR cerebral[tiab]) AND metastas*[tiab]

$310 R 2$

4 "Carcinoma, Small Cell" $[\mathrm{mh}]$

5 SCLC[tiab]

6 ([small[tiab] AND cell[tiab]) AND (carcinoma*[tiab] OR cancer*[tiab] OR adenocarcinoma*[tiab] OR malignan*[tiab] OR tumor[tiab] OR tumors[tiab] OR tumour*[tiab] OR neoplasm*[tiab])]

? ([reserve[tiab] AND cell[tiab]) AND (carcinoma*[tiab] OR cancer*[tiab] OR adenocarcinoma*[tiab] OR malignan*[tiab] OR tumor[tiab] OR tumors[tiab] OR tumour*[tiab] OR neoplasm*[tiab])]

8 ([oat[tiab] AND cell[tiab]) AND (carcinoma*[tiab] OR cancer*[tiab] OR 
adenocarcinoma*[tiab] OR malignan*[tiab] OR tumor[tiab] OR tumors[tiab] OR

tumour*[tiab] OR neoplasm*[tiab]])

96 OR $>$ OR 8

10 lung*[tiab] OR pulmonary[tiab] OR bronchus[tiab] OR brochogenic[tiab] OR bronchial[tiab] OR bronchoalveolar[tiab] OR alveolar[tiab]

119 AND 10

124 OR 5 OR 11

133 AND 12

\section{B: Reference searching}

Further, reference lists from identified studies were scrutinised for any other additional studies. All searches were conducted without any limitation for language.

\section{Methods of review}

The following criteria were used to select studies for inclusion in this review:

1) Design: randomized controlled or clinical controlled trials in which the response of synchronous BM to first-line systemic chemotherapy is evaluated and reported

2) Population: Patients with SCLC and BM diagnosed within 4 weeks after the diagnosis of SCLC (initial/synchronous BM).

3) Intervention: first-line systemic chemotherapy

4) Outcomes:

- Radiological response

- Progression free survival (time to radiological progression of BM]

The titles and abstracts in MEDLINE and the Cochrane library were reviewed. Any article that deemed to satisfy the inclusion criteria was retrieved. Also articles were retrieved if it was felt that the reference list should be reviewed.

All studies were evaluated in order to assess whether the studies match the inclusion criteria. To evaluate the methodological quality of selected RCTs and other studies, 
we assessed the methods section of the trials, considering the randomization process, the presence of adequate concealment, the description of follow-up and the reporting of losses of included patients.

\section{Statistical analysis:}

The statistical analysis would be conducted with the RCTs or CCTs included. Where possible, outcomes from included trials would be combined using Review Manager. Relative risk and risk differences with 95\% confidence intervals would be reported. To detect heterogeneity, the random effects model would have been used. For survival analysis, estimation of the hazard ratio and its variance would be used as the summary statistic. All analyses would be conducted on an intention-to-treat basis.

\section{Description of studies}

Of the 539 references found in the electronic search, 36 studies were selected for further evaluation. No RCTs or CCTs were found. However a number of observational studies and/or case series were retrieved. A second judgement cut down to 11 studies reporting on the effect of first-line systemic chemotherapy on BM from SCLC. Although no statistical analysis was conducted with these studies, we did evaluate them in order to assess whether they contribute to the debate concerning the effect of systemic chemotherapy on BM from SCLC.

Table 1 shows a summary of the results of the 11 studies evaluated. Study details regarding 'patients and methods' are described below. In all studies, except one12, CT was used to establish the diagnosis of BM. Unless otherwise stated cranial irradiation was not included in the initial treatment protocol.

Kantarjian 1984 and Kearns 1989 both described two SCLC patients (case reports)

with a complete intracranial radiologic response after initial chemotherapy.16,17 The remaining nine studies were observational and used data from an existing database or a case series.

The study of Conte 1981 reported a series of 44 patients with central nervous system 


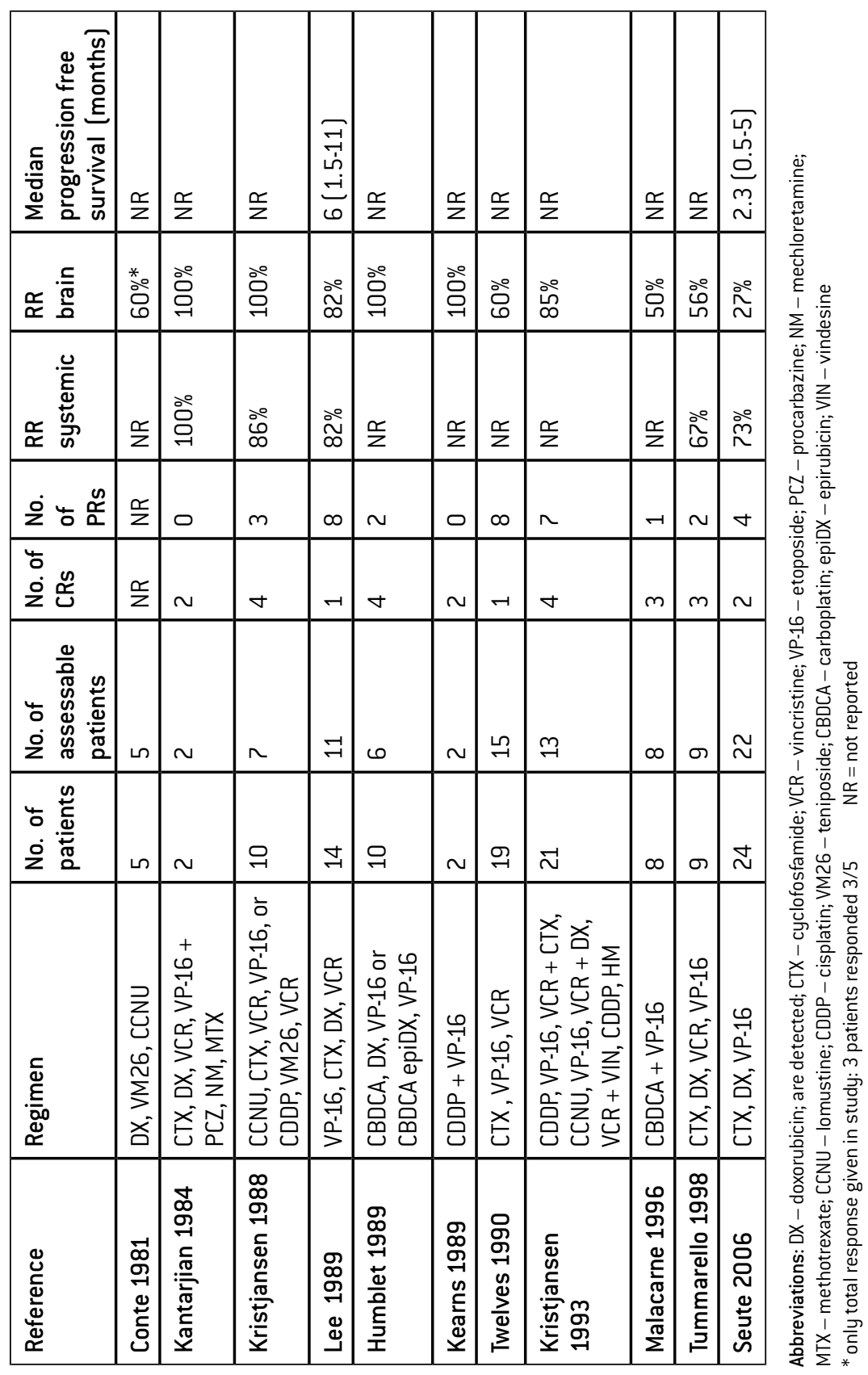


metastases from various primary tumors. ${ }^{18}$ This series included five SCLC patients with BM.

Kristjansen 1988 reported on ten SCLC patients with BM treated with chemotherapy at their institution.19 Three patients died within three weeks after the diagnosis of SCLC, leaving $?$ patients eligible for response evaluation.

In the study of Lee 1989 the response of BM was evaluated after three courses of chemotherapy in $11 \mathrm{SCLC}$ patients. ${ }^{20} \mathrm{CT}$ scan of the brain was part of the screening procedure and five patients included had asymptomatic BM. Three patients were not assessable for response. Two patients who died early and a third patient received WBRT after the first course of chemotherapy. In this study patients with major neurological signs or symptoms were considered ineligible and were excluded from the study. WBRT ( $30 \mathrm{~Gy}$ ) was included in the treatment protocol and given concurrently with the fourth course of chemotherapy.

The study of Humblet 1989 was a multi-center open trial, in the first place conducted to determine the maximal tolerable dose of carboplatin in combination with conventional doses of both etiposide and an anthracycline for the treatment of SCLC patients. ${ }^{21}$ The second objective of this study was to evaluate the anti-tumor activity of these chemotherapy regimens. Of the ten patients included in this study with BM at diagnosis, two died early from toxicity another two patients received irradiation before chemotherapy. Six patients were evaluable for response to chemotherapy.

Twelves 1990 describes the response of BM to chemotherapy in a subgroup of SCLC patients included in a multi-center randomized chemotherapy trial. ${ }^{22,23}$ Patients were randomized to receive initially either four or eight courses of cytotoxic chemotherapy with cyclophosphamide, vincristine and etoposide. Nineteen patients were diagnosed with synchronous BM. Evaluation for response of BM took place after four courses of chemotherapy. Five patients did undergo a second brain scan. Four of these had rapid deterioration in neurologic state during chemotherapy and were classified as non-responders. The remaining patient had a complete resolution of neurological symptoms and signs and was considered a clinical responder.

The study of Kristjansen also describes a subgroup of SCLC patients included in a multi-center trials. ${ }^{24}$ Twenty-one patients with synchronous BM were enrolled. They all 
received the same treatment regimen. This regimen was one of the treatment regimens in a concurrent 3-armed randomized trial. Eight patients were not evaluable because of early death, leaving 13 patients assessable for response.

Malacarne 1996 reported a series of 30 consecutive patients with BM from lung cancer. ${ }^{25}$ Twelve patients had SCLC. Eight patients were eligible since four patients were previously treated with chemotherapy (platinum derivatives). In 16 patients the BM diagnosed were asymptomatic, however the study does not report whether it concerned SCLC patients, NSCLC patients or both.

Tummarello 1998 reports on a series of 23 lung cancer patients with BM. ${ }^{26}$ Nine patients had SCLC and were all assessable for response evaluation. The BM were diagnosed by CT, followed in some cases by MRI after treatment. The study does not report how many and which patients underwent MRI. Eight patients had asymptomatic BM, it is not reported whether these were SCLC patients, NSCLC patients or both.

The study of Seute reports on a consecutive series of 24 SCLC patients with asymptomatic BM diagnosed through MRI. ${ }^{12}$ Two patients did not undergo a second MRI, because of early death and poor clinical condition respectively. Response evaluation was performed by an experienced neuro-radiologist who was not aware of the patients' systemic response.

\section{Methodological quality}

There were no studies that fulfilled the criteria of inclusion.

\section{Results}

To date we have not found any reports of randomized or controlled clinical trials in which the response of synchronous BM to first-line systemic chemotherapy is evaluated. Twelves et al. and Kristjansen et al. described a subgroup of patients included in one treatment arm of randomized trials. ${ }^{22,24}$ 


\section{Discussion}

The last review written and published on the subject of systemic chemotherapy for BM from SCLC dates from 1992. Kristensen et al. reviewed the literature concerning chemotherapy for BM from SCLC. ${ }^{3}$ In this review data were pooled and a total response rate (RR) of $76 \%$ was reported. The authors concluded that there was "adequate evidence suggesting that initial BM from SCLC respond to systemic chemotherapy as does extracranial disease". Moreover they stated that "first-line cranial radiotherapy is not necessary, even though it had not been documented in randomized settings". After 1992 three more studies were published in which the above statement was supported by the authors. ${ }^{24-26}$ Seute et al. however could not confirm the results from former studies. They found a substantially lower RR $[27 \%$ ] of initial BM to chemotherapy, compared to a systemic RR of $73 \%$ in their patient group. ${ }^{12}$ Hence the debate about the optimal treatment for synchronous BM from SCLC and the role of chemotherapy within is currently still ongoing. To add relevant information for this debate the present systematic review was undertaken.

We did not find any trials that answered the research question of this review and therefore no studies were subjected to a statistical analysis. However we did discuss the case reports and the observational studies reporting on the effect of systemic chemotherapy on synchronous BM from SCLC. The radiological RR varied from $27 \%$ to $100 \%$. The progression free survival time was reported in only two studies.

The evaluated studies had several shortcomings. The results reported were liable to selection bias, since in all studies patients who could not undergo or complete the chemotherapy regimen were excluded from assessment of response. This may have led to an overestimation of the true therapeutic effect. Also six studies failed to report on how the patient group was obtained. Furthermore, apart from the study of Seute et al., the manuscripts did not mention how and by whom the RR was assessed. If the assessor was aware of the systemic response of the patients, expectation bias may have led to an overestimation of the association between systemic and cranial response.

In addition, different treatment regimens were used and in some studies even 
cranial irradiation was included in the treatment protocol. Because it is known that BM respond to irradiation, the RR from chemotherapy will probably have been overestimated. Furthermore, since observational studies are more vulnerable for selective publication based on the direction of their findings, we reason that the occurrence of publication bias should be seriously considered in this matter. ${ }^{27}$

In summary, after a thorough electronic search we found 11 observational studies or case reports concerning the effect of first-line systemic chemotherapy on synchronous BM from SCLC. The study methods as well as the reported RRs varied widely. In the absence of direct evidence on the effectiveness of chemotherapy for synchronous BM, we can only conclude that further research by prospective trials should be carried out.

\section{Authors' conclusions}

\section{Implication for practice}

At present there is insufficient evidence about the effectiveness of first-line systemic chemotherapy for synchronous BM from SCLC. We therefore argue that WBRT should not be withheld from SCLC patients diagnosed with synchronous BM.

\section{Implications for research}

The difficulty with providing evidence for the research question of this review lies in the fact that the intervention (first-line chemotherapy) administered is in the first place to treat the primary tumor. The effect of chemotherapy on BM is actually a beneficial side effect and hence at bests a secondary endpoint in the event of a trial. Because it would be considered unethical to withhold patients from treatment of the primary tumor a randomized or clinical controlled trial comparing chemotherapy to placebo is impossible to conduct. However a trial in which patients are randomized to two different regimens of chemotherapy could be conducted. In a suchlike trial imaging of the brain (preferably MRI] should be part of the staging procedure. The RRs and progression free survival times should then be reported separately for symptomatic BM and asymptomatic BM. 


\section{References}

1. Seute T, Leffers P, ten Velde GP, et al: Neurologic disorders in 432 consecutive patients with small cell lung carcinoma. Cancer 100:801-6, 2004

2. Pease NJ, Edwards A, Moss LJ: Effectiveness of whole brain radiotherapy in the treatment of brain metastases: a systematic review. Palliat Med 19:288-99, 2005

3. Kristensen CA, Kristjansen PE, Hansen HH: Systemic chemotherapy of brain metastases from small-cell lung cancer: a review. J Clin Oncol 10:1498-502., 1992

4. Nieder C, Grosu AL, Astner S, et al: Integration of chemotherapy into current treatment strategies for brain metastases from solid tumors. Radiat Oncol 1:19, 2006

5. Siegers HP: Chemotherapy for brain metastases: recent developments and clinical considerations. Cancer Treat Rev 17:63-76, 1990

6. Stewart DJ, Lu K, Benjamin RS, et al: Concentration of vinblastine in human intracerebral tumor and other tissues. J Neurooncol 1:139-44, 1983

7. Stewart DJ, Richard MT, Hugenholtz H, et al: Penetration of teniposide (VM-26) into human intracerebral tumors. Preliminary observations on the effect of tumor type, rate of drug infusion and prior treatment with amphotericin B or oral glycerol. J Neurooncol 2:315-24, 1984

8. Stewart DJ: A critique of the role of the blood-brain barrier in the chemotherapy of human brain tumors. J Neurooncol 20:121-39, 1994

9. Schuette W: Treatment of brain metastases from lung cancer: chemotherapy. Lung Cancer 45 Suppl 2:S253-?, 2004

10. van den Bent MJ: The role of chemotherapy in brain metastases. Eur J Cancer 39:2114-20, 2003

11. Postmus PE, Smit EF: Chemotherapy for brain metastases of lung cancer: a review. Ann Oncol 10:753-9, 1999

12. Seute T, Leffers P, Wilmink JT, et al: Response of asymptomatic brain metastases from small-cell lung cancer to systemic first-line chemotherapy. J Clin Oncol 24:2079-83, 2006 
13. Grossi F, Scolaro T, Tixi L, et al: The role of systemic chemotherapy in the treatment of brain metastases from small-cell lung cancer. Crit Rev Oncol Hematol 37:61-?., 2001

14. Soffietti R, Costanza A, Laguzzi E, et al: Radiotherapy and chemotherapy of brain metastases. J Neurooncol 75:31-42, 2005

15. Macdonald DR, Cascino TL, Schold SC, Jr., et al: Response criteria for phase II studies of supratentorial malignant glioma. J Clin Oncol 8:1277-80, 1990

16. Kantarjian H, Farha PA, Spitzer G, et al: Systemic combination chemotherapy as primary treatment of brain metastasis from lung cancer. South Med J 77:426-30, 1984

17. Kearns F, Grogan L, Harford P, et al: Resolution of small cell lung cancer intracranial metastases with standard dose chemotherapy. Ir J Med Sci 158:308-9, 1989

18. Conte PF, Giaccone G, Musella R, et al: Combination chemotherapy for metastatic brain tumors. Tumori 67:559-62, 1981

19. Kristjansen PE, Hansen $\mathrm{HH}$ : Brain metastases from small cell lung cancer treated with combination chemotherapy. Eur J Cancer Clin Oncol 24:545-9., 1988

20. Lee JS, Murphy WK, Glisson BS, et al: Primary chemotherapy of brain metastasis in small-cell lung cancer. J Clin Oncol 7:916-22, 1989

21. Humblet Y, Weynants P, Bosly A, et al: Carboplatin in association with etoposide and either adriamycin or epirubicin for untreated small cell lung cancer: a dose escalation study of carboplatin. UCL Clinical Oncology Group. Med Oncol Tumor Pharmacother 6:207-12, 1989

22. Twelves CJ, Souhami RL, Harper PG, et al: The response of cerebral metastases in small cell lung cancer to systemic chemotherapy. Br J Cancer 61:147-50., 1990

23. Spiro SG, Souhami RL, Geddes DM, et al: Duration of chemotherapy in small cell lung cancer: a Cancer Research Campaign trial. Br J Cancer 59:578-83, 1989

24. Kristjansen PE, Soelberg Sorensen P, Skov Hansen M, et al: Prospective evaluation of the effect on initial brain metastases from small cell lung cancer of platinum-etoposide based induction chemotherapy followed by an alternating multidrug regimen. Ann Oncol 4: 579-83., 1993

25. Malacarne P, Santini A, Maestri A: Response of brain metastases from lung cancer to systemic chemotherapy with carboplatin and etoposide. Oncology 53:210-3, 1996 
26. Tummarello D, Lippe P, Bracci R, et al: First line chemotherapy in patients with brain metastases from non- small and small cell lung cancer. Oncol Rep 5:897-900., 1998

27. Stroup DF, Berlin JA, Morton SC, et al: Meta-analysis of observational studies in epidemiology: a proposal for reporting. Meta-analysis Of Observational Studies in Epidemiology (MOOSE) group. Jama 283:2008-12, 2000 



$$
\begin{gathered}
6 \\
\text { Response of asymptomatic brain metastases } \\
\text { from Small Cell Lung Cancer } \\
\text { to systemic first-line chemotherapy }
\end{gathered}
$$

Presented at the $57^{\text {th }}$ annual meeting of the American Academy of Neurology, April 2005, Miami, USA

Tatjana Seute, Pieter Leffers, Jan T. Wilmink, Guul P.M. ten Velde and Albert Twijnstra

Journal of Clinical Oncology 2006; 24: 2079-2083 


\section{Purpose}

The purpose of this study was to investigate the radiologic response of asymptomatic brain metastases (BM) from small-cell lung cancer (SCLC) to first-line systemic chemotherapy.

\section{Patients and methods}

From 1990 to 2003, 181 consecutive patients with SCLC were enrolled onto this study. Patients were examined by a neurologist on a regular basis. Magnetic resonance imaging (MRI) of the brain was performed routinely before (at diagnosis of SCLC) and after first-line systemic chemotherapy. Patients were treated with combination chemotherapy consisting of cyclophosphamide, doxorubicin, and etoposide. Clinically manifest BM were treated with whole-brain radiotherapy (WBRT). The response rate (RR) of BM was assessed by changes in the size or the number of enhanced lesions on MRI using standard criteria.

\section{Results}

Synchronous asymptomatic BM were found in 24 SCLC patients (13\%). In six (27\%) of the 22 assessable patients, the asymptomatic BM responded to systemic chemotherapy. A systemic response was found in 16 patients (73\%). All patients became symptomatic during follow-up. The symptom-free survival did not differ between cranial responders and cranial nonresponders.

\section{Conclusions}

The RR of asymptomatic BM from SCLC to systemic chemotherapy is $27 \%$ and evidently lower than the systemic RR. Future studies should focus on the possible beneficial effect of WBRT for patients with asymptomatic synchronous BM. 


\section{Introduction}

Brain metastases (BM) are a frequent and devastating complication in patients with a malignancy. At autopsy, BM are found in approximately $25 \%$ of patients who die of cancer. Although any systemic cancer can metastasize to the brain, lung cancer, breast cancer, and melanoma are the most common primary tumors. ${ }^{1}$ At the time of diagnosis, at least $18 \%$ of the patients with small-cell lung cancer (SCLC) have symptomatic or asymptomatic BM. ${ }^{2}$

The aims of treatment of symptomatic BM from SCLC are to reduce symptoms and to prevent complications, such as neurologic deficits and cognitive impairment. The standard treatment is whole-brain radiotherapy (WBRT), with reported response rates (RRs) ranging from $56 \%$ to $92 \%{ }^{3,4}$

For a long time, the brain was considered a pharmacologic sanctuary in which metastases could grow under the protection of the blood-brain barrier (BBB). However, in recent decades, it has become clear that the BBB is disrupted in metastatic tumor tissue..$^{5-8}$ Since then, the effectiveness of first-line and second-line systemic chemotherapy for the treatment of BM from SCLC has been the topic of several studies. ${ }^{9.14}$

Several authors claimed that synchronous BM show a good RR to systemic chemotherapy that is similar to the RR for the primary tumor. ${ }^{15.17}$ Pooled data from seven studies show a $79 \%$ RR of synchronous symptomatic BM from SCLC to first-line systemic chemotherapy (Table 1). ${ }^{18-24}$

On the basis of these studies, it has been suggested that BM from SCLC should initially be treated with systemic chemotherapy. ${ }^{4}$ The debate about whether WBRT should be part of the initial treatment is still ongoing. ${ }^{25}$

To add relevant information for this debate, we studied the radiologic response of asymptomatic BM from SCLC to first-line systemic chemotherapy. The data were derived from an ongoing register in which neurologic complications of SCLC are documented. ${ }^{2}$ All patients in our study underwent routine imaging of the brain at diagnosis of SCLC, enabling us to detect patients with symptomatic and asymptomatic BM. In the asymptomatic patient 
Table 1. Response of BM From SCLC to First-Line Chemotherapy in Earlier Studies

\begin{tabular}{|c|c|c|c|c|c|c|}
\hline Reference & Regimen & $\begin{array}{l}\text { No. of } \\
\text { Patients }\end{array}$ & $\begin{array}{c}\text { No. of } \\
\text { Asses- } \\
\text { sable } \\
\text { Patients }\end{array}$ & $\begin{array}{c}\text { No. } \\
\text { of } \\
\text { CRs }\end{array}$ & $\begin{array}{c}\text { No. } \\
\text { of } \\
\text { PRs }\end{array}$ & $\begin{array}{c}\text { Overall } \\
\text { Clinical } \\
\text { Respon- } \\
\text { se [\%] }\end{array}$ \\
\hline $\begin{array}{l}\text { Kantarjian } \\
\text { et al, }{ }^{18} 1984\end{array}$ & $\begin{array}{l}\text { CTX, DX, VCR, VP-16 } \\
\text { + PCZ, NM, MTX }\end{array}$ & 2 & 2 & 2 & 0 & 100 \\
\hline $\begin{array}{l}\text { Kristjansen and } \\
\text { Hansen, } 191988\end{array}$ & $\begin{array}{l}\text { CCNU, CTX, VCR, VP-16 } \\
\text { or CDDP, VM26, VCR }\end{array}$ & 10 & 7 & 4 & 3 & 100 \\
\hline $\begin{array}{l}\text { Lee et al, }{ }^{20} \\
1989\end{array}$ & VP-16, CTX, DX, VCR & 14 & 11 & 1 & 8 & 82 \\
\hline $\begin{array}{l}\text { Humblet et al, } \\
1989\end{array}$ & $\begin{array}{l}\text { CBDCA, DX, VP-16 or } \\
\text { CBDCA epiDX, VP-16 }\end{array}$ & 10 & 6 & 4 & 2 & 100 \\
\hline $\begin{array}{l}\text { Twelves et al, }{ }^{22} \\
1990\end{array}$ & CTX, VP-16, VCR & 19 & 14 & 1 & 8 & 47 \\
\hline $\begin{array}{l}\text { Kristjansen et } \\
\mathrm{al}^{23} 1993\end{array}$ & $\begin{array}{l}\text { CDDP, VP-16, VCR + CTX, } \\
\text { CCNU, VP-16, VCR + DX, } \\
\text { VCR + VIN, CDDP, HM }\end{array}$ & 21 & 13 & 4 & 7 & 85 \\
\hline $\begin{array}{l}\text { Tumarello et } \\
\mathrm{al}^{24} 1998\end{array}$ & CTX, DX, VCR, VP-16 & 9 & 9 & 3 & 2 & 56 \\
\hline Total & - & 85 & 62 & 19 & 30 & 79 \\
\hline
\end{tabular}

Abbreviations: BM, brain metastases; SCLC, small-cell lung cancer; CR, complete response; PR, partial response; CTX, cyclophosphamide; DX, doxorubicin; VCR, vincristine; VP-16, etoposide; PCZ, procarbazine; NM,

mechlorethamine; MTX, methotrexate; CCNU, lomustine; CDDP, cisplatin; VM26, teniposide; CBDCA, carboplatin; epiDX, epirubicin; VIN, vindesine; HM, hexamethylmelamine.

group, the effect of first-line chemotherapy could be measured without interference of cranial irradiation.

\section{Patients and Methods}

\section{Patients}

From January 1990 to May 2003, 181 consecutive patients with microscopically or histologically proven SCLC were enrolled onto this study. Patients were diagnosed and 
treated at the University Hospital Maastricht (Maastricht, the Netherlands). Potential follow-up time for all patients was at least 1 year. Patients were initially staged by a pulmonologist. Physical examination, routine blood and chemistry profile, chest $x$-ray, computed tomography (CT) scan of the chest, and fiberoptic bronchoscopy were routinely performed. All patients underwent treatment and diagnostic evaluation according to the standard protocol used in our hospital.

\section{Neurologic Follow-Up}

The same experienced neurologist (A.T.) examined all patients at diagnosis, every 3 months during the first year, and every 6 months thereafter. Magnetic resonance imaging (MRI) of the brain was performed before (at diagnosis of SCLC) and after initial chemotherapy. An additional brain MRI scan was performed when patients had survived for 12 months after the diagnosis of SCLC. If new neurologic symptoms or signs arose, the frequency of neurologic consultations and diagnostics was increased.

\section{Treatment Plan}

All patients were initially treated with combination chemotherapy, consisting of cyclophosphamide $1,000 \mathrm{mg} / \mathrm{m}^{2}$ and doxorubicin $45 \mathrm{mg} / \mathrm{m}^{2}$ on day 1 and etoposide $100 \mathrm{mg} / \mathrm{m}^{2}$ on days 1,3 , and 5 , repeated every 3 weeks, with a maximum of five cycles. Patients received dexamethasone $8 \mathrm{mg}$ at the start of each cycle as an antiemetic.

Clinically manifest BM were treated with WBRT with fractions of $3 \mathrm{~Gy}$ administered five times a week up to a total dose of $30 \mathrm{~Gy}$. In the case of cerebral edema, patients received corticosteroid medication.

\section{Response Evaluation}

Response of the asymptomatic BM to chemotherapy was assessed by changes in the size or the number of enhanced lesions on MRI scans (0.5T system), before and after chemotherapy. MRI scans were made before and after intravenous injection of the MRI contrast medium gadolinium diethylenetriaminepentaacetic acid in a dose of $0.1 \mathrm{mmol} / \mathrm{kg}$. 
The MRI technique stayed the same over the study period. The MRI scans were reviewed by an experienced neuroradiologist (J.T.W.). The neuroradiologist had not seen the patients in person and was not aware of the patients' systemic response. Response was assessed using the standard criteria according to the WHO handbook for reporting results of cancer treatment.26 Complete remission was defined as the complete disappearance of all tumor lesions on MRI. Partial remission was defined as an at least $50 \%$ decrease of total tumor size of the lesions that had been measured, without the appearance of any new lesions or progression of any lesions. Stable disease was defined as a less than $50 \%$ decrease or less than $25 \%$ increase in size of lesions and no new lesions. Progressive disease was defined as a more than $25 \%$ increase in the size of lesions or the appearance of new lesions.

The response of the primary tumor and systemic metastases was measured by CT of the thorax and CT of the abdomen. The same criteria were used as described earlier.

Table 2. Patient Characteristics at Diagnosis of Small-Cell Lung Cancer

\begin{tabular}{|c|c|c|c|c|}
\hline \multirow[b]{2}{*}{ Characteristic } & \multicolumn{2}{|c|}{ Symptomatic BM $(n=14)$} & \multicolumn{2}{|c|}{ Asymptomatic BM $(n=24)$} \\
\hline & No. of Patients & $\%$ & No. of Patients & $\%$ \\
\hline \multicolumn{5}{|l|}{ Age, years } \\
\hline - Median & \multicolumn{2}{|l|}{68} & \multicolumn{2}{|l|}{66} \\
\hline - Range & \multicolumn{2}{|l|}{$49-81$} & \multicolumn{2}{|l|}{$46-82$} \\
\hline Male & 13 & 93 & 18 & 75 \\
\hline BM only & 3 & 21 & 5 & 21 \\
\hline BM in posterior fossa & $?$ & 50 & 19 & 80 \\
\hline \multicolumn{5}{|l|}{ Other metastatic sites } \\
\hline - Bone & $?$ & 50 & 10 & 42 \\
\hline - Liver & 1 & 7 & 8 & 33 \\
\hline - Mediastinum & 4 & 29 & 4 & 17 \\
\hline - Other & 7 & 50 & 10 & 42 \\
\hline
\end{tabular}




\section{Statistics}

The Wilson score method was used to estimate 95\% Cls for RRs. The McNemar test was used to test for differences in RRs of BM and systemic metastases. Survival curves were estimated by the Kaplan-Meier method.27 Differences between survival curves were tested with the log-rank test. $P<.05$ was considered statistically significant.

\section{Results}

Among the 181 patients, there were 38 patients (21\%) with synchronous BM. In 24 of these patients (13\%), the BM were asymptomatic. The characteristics of all patients with synchronous BM are listed in Table 2.

Two of the asymptomatic patients were not treated; one patient was not treated because of his poor physical condition, and one patient died during the first course of chemotherapy. The other 22 patients completed five cycles of first-line chemotherapy and were, therefore, assessable for response. Twenty-one patients received an MRI scan of the brain after chemotherapy. Because of claustrophobia, one patient underwent a CT scan instead. None of the patients received cranial irradiation before or during first-line chemotherapy.

Table 3. Response to First-Line Chemotherapy in Small-Cell Lung Cancer Patients

\begin{tabular}{|c|c|c|c|c|c|c|}
\hline \multirow[b]{2}{*}{ Response } & \multicolumn{4}{|c|}{$\begin{array}{l}\text { Systemic Response } \\
\text { (No. of patients }\end{array}$} & \multirow[b]{2}{*}{ Total (brain response) } & \\
\hline & CR & PR & SD & PD & & \\
\hline CR & 2 & & & & 2 & \multirow{2}{*}{$27 \%$} \\
\hline PR & 3 & & 1 & & 4 & \\
\hline SD & 1 & 3 & & 1 & 5 & \\
\hline PD & 1 & 6 & 2 & 2 & 11 & \\
\hline \multirow[t]{2}{*}{ Total (systemic response) } & 7 & 9 & 3 & 3 & 22 & \\
\hline & \multicolumn{2}{|c|}{$73 \%$} & & & & \\
\hline
\end{tabular}

Abbreviations: CR, complete response; PR, partial response; PD, progressive disease; SD, stable disease. 
The response of the asymptomatic BM and the systemic response (primary tumor and extracranial metastases) after initial chemotherapy are listed in Table 3. In six of the 22 asymptomatic patients, the BM responded to chemotherapy, whereas a systemic response was found in 16 of these patients. The brain response (27\%; 95\% $\mathrm{Cl}, 13 \%$ to $48 \%$ ) was significantly less $(P=.006)$ than the systemic response $(73 \% ; 95 \% \mathrm{Cl}, 52 \%$ to $87 \%$ ). In 10 patients, systemic response and cranial response were equal. Five of the six patients with responding $\mathrm{BM}$ were a subset of the 16 systemic responders.

Three patients became symptomatic during the last cycle of first-line chemotherapy. All other 19 patients became symptomatic after completing chemotherapy, with a median duration of 2.3 months (range, 0.5 to 5 months) measured from the last day of the fifth chemotherapy cycle. The two patients with a cranial complete response had a symptomfree period of 3 and 4 months. Figure 1 shows that the symptom-free survival in patients with asymptomatic BM did not clearly differ between cranial responders and cranial nonresponders to chemotherapy.

Figure 1. Kaplan-Meier survival curve showing symptom-free survival of small-cell lung cancer patients with asymptomatic brain metastases measured from the last day of the fifth chemotherapy cycle $[P=.4497)$. $P R$, partial response; $C R$, complete response; $P D$, progressive disease; SD, stable disease

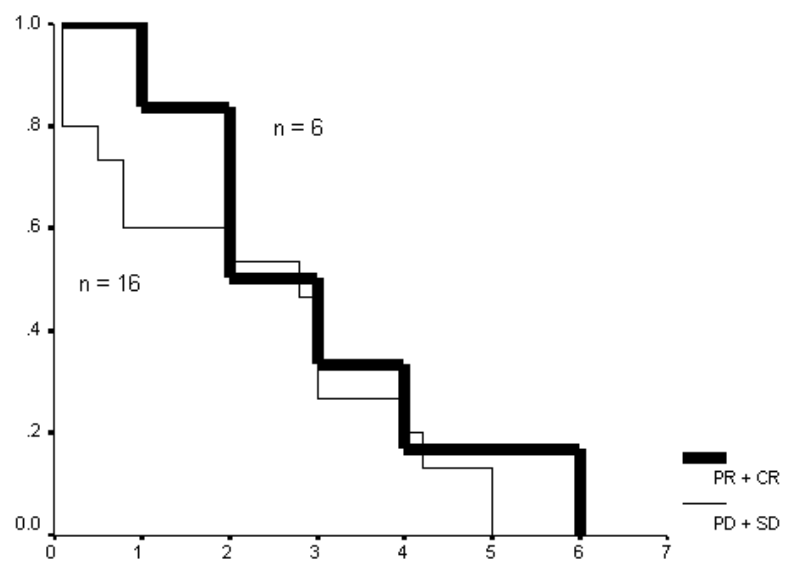

survival time (months) 
Patients with asymptomatic BM $(n=22)$ had a median survival time of 8.3 months (range, 1.3 to 43.4 months). Patients with symptomatic BM who received WBRT ( $n=9$ ) had a median survival time of 10.5 months (range, 1.7 to 34.5 months). Five symptomatic patients did not receive WBRT because of their poor clinical condition; they had a median survival time of 6.9 months (range, 1.0 to 12.7 months). The percentage of patients who were assumed to have died as an immediate result of BM was similar for asymptomatic and symptomatic patients ( $41 \%$ and $36 \%$, respectively).

\section{Discussion}

In the present study, we investigated the radiologic response of synchronous asymptomatic BM from SCLC to first-line combination chemotherapy. Previous studies (Table 1) found a high RR of synchronous BM from SCLC to chemotherapy (RR, 79\%). These and other studies have led to the current view that first-line chemotherapy is a sufficient initial treatment in SCLC patients with synchronous BM and that WBRT may be deferred until symptoms arise. ${ }^{3,4}$ However, these studies had several shortcomings. First, in most studies, patients with a variety of treatment regimens were mixed, and some studies even included cranial irradiation before evaluation of response..$^{22}$ Because it is known that BM respond to radiation, the RR from chemotherapy will probably have been overestimated. Second, the reports did not state who determined the RR and whether the assessor was aware of the clinical state of the patients and their systemic response. Therefore, expectation bias may have led to overestimation of the association between systemic and cranial response. Finally and most importantly, no direct comparison was made with systemic response in the same patients.

In our study, 22 of the 24 asymptomatic patients were assessable, and all received the same treatment. None of these patients underwent cranial irradiation before or during chemotherapy. RR of BM was evaluated by MRI scanning, which is more sensitive than CT for the detection of BM. ${ }^{28}$ Radiologic response was evaluated blindly. The number of 
patients included in the present analysis is larger than the number of patients in previous studies (Table 1). However, the number is still relatively small, and therefore, caution should be used when interpreting the data.

In our study, the radiologic RR of asymptomatic BM was only $27 \%$, whereas the systemic RR was 73\% ( Table 3). The cranial RR in asymptomatic patients was substantially lower than the cranial RR found in earlier studies with symptomatic BM patients (Table 1]. We further found that almost all cranial responders responded systemically but that systemic response did not guarantee a cranial response at all (Table 3). These findings contradict the postulated idea that the cranial response to chemotherapy is equal to the response of systemic metastases and the primary tumor. ${ }^{16,17}$

The most striking difference between our study and earlier publications is that our BM patients were asymptomatic. One might argue that the BBB is less disrupted in patients with asymptomatic BM and, therefore, smaller amounts of chemotherapeutic agents can reach the tumor sites. ${ }^{29}$ However, this argument is contradicted by the fact that symptomatic as well as asymptomatic BM enhance on MRI after intravenous injection of gadolinium

It is known that corticosteroid treatment can partly restore the BBB. ${ }^{30}$ The symptomatic BM patients in the earlier studies probably received high doses of corticosteroids to diminish cerebral edema. Hence, the low dose of corticosteroids administered as an antiemetic treatment alone cannot be held responsible for the lower cranial RR in our patient group.

In our patient group, symptom-free survival did not differ between responders and nonresponders (Fig 1). Therefore, even in the patients with a radiologic response, it seems that systemic chemotherapy is not able to postpone the occurrence of symptoms of BM. Because the number of patients in this analysis (Fig 1) is small, this conclusion only tentatively supports the notion that chemotherapy is not effective against BM.

The clinical relevance of the findings of our study is the fact that, after the completion of chemotherapy, there remains a substantial number of patients who still have asymptomatic BM. Therefore, initial chemotherapy is not sufficiently effective 
for treatment of BM, and the question of whether symptoms in these patients can be postponed by WBRT becomes a relevant topic for future research.

In conclusion, the RR of asymptomatic BM from SCLC to systemic chemotherapy is $27 \%$ [ $95 \% \mathrm{Cl}, 13 \%$ to $48 \%$ ) and the response of asymptomatic BM to systemic chemotherapy is much lower than the systemic response. Future studies should focus on the possible beneficial effect of WBRT for patients with asymptomatic synchronous BM. 


\section{References}

1. Posner J: Neurologic Complications of Cancer. Philadelphia, PA, F.A. Davis Company, 1995

2. Seute T, Leffers P, ten Velde GP, et al: Neurologic disorders in 432 consecutive patients with small cell lung carcinoma. Cancer 100:801-806, 2004

3. Postmus PE: Brain metastases from small cell lung cancer: Chemotherapy, radiotherapy, or both? Semin Radiat Oncol 5:69-73, 1995

4. Grossi F, Scolaro T, Tixi L, et al: The role of systemic chemotherapy in the treatment of brain metastases from small-cell lung cancer. Crit Rev Oncol Hematol 37:61-67, 2001

5. Siegers HP: Chemotherapy for brain metastases: Recent developments and clinical considerations. Cancer Treat Rev 17:63-76, 1990

6. Stewart DJ, Lu K, Benjamin RS, et al: Concentration of vinblastine in human intracerebral tumor and other tissues. J Neurooncol 1:139-144, 1983

7. Stewart DJ, Richard MT, Hugenholtz H, et al: Penetration of teniposide (VM-26) into human intracerebral tumors: Preliminary observations on the effect of tumor type, rate of drug infusion and prior treatment with amphotericin B or oral glycerol. J Neurooncol 2:315-324, 1984

8. Stewart DJ: A critique of the role of the blood-brain barrier in the chemotherapy of human brain tumors. J Neurooncol 20:121-139, 1994

9. Franciosi V, Cocconi G, Michiara M, et al: Front-line chemotherapy with cisplatin and etoposide for patients with brain metastases from breast carcinoma, nonsmall cell lung carcinoma, or malignant melanoma: A prospective study. Cancer 85:1599-1605, 1999

10. Boogerd W, Dalesio 0, Bais EM, et al: Response of brain metastases from breast cancer to systemic chemotherapy. Cancer 69:972-980, 1992

11. Postmus PE, Smit EF, Berendsen HH, et al: Treatment of brain metastases of small cell lung cancer with teniposide. Semin Oncol 19:89-94, 1992

12. Groen HJ, van der Leest AH, de Vries EG, et al: Continuous carboplatin infusion during 6 weeks' radiotherapy in locally inoperable non-small-cell lung cancer: A phase I and pharmacokinetic study. Br J Cancer 72:992-997, 1995 
13. Korfel A, Oehm C, von Pawel J, et al: Response to topotecan of symptomatic brain metastases of small-cell lung cancer also after whole-brain irradiation: A multicentre phase II study. Eur J Cancer 38:1724-1729, 2002

14. Postmus PE, Haaxma-Reiche H, Smit EF, et al: Treatment of brain metastases of small-cell lung cancer: Comparing teniposide and teniposide with whole-brain radiotherapy $-\mathrm{A}$ phase III study of the European Organization for the Research and Treatment of Cancer Lung Cancer Cooperative Group. J Clin Oncol 18:3400-3408, 2000

15. Kristensen CA, Kristjansen PE, Hansen HH: Systemic chemotherapy of brain metastases from small-cell lung cancer: A review. J Clin Oncol 10:1498-1502, 1992

16. Van den Bent MJ: The role of chemotherapy in brain metastases. Eur J Cancer 39:2114-2120, 2003

17. Postmus PE, Smit EF: Chemotherapy for brain metastases of lung cancer: A review. Ann Oncol 10:753-759, 1999

18. Kantarjian H, Farha PA, Spitzer G, et al: Systemic combination chemotherapy as primary treatment of brain metastasis from lung cancer. South Med J 77:426-430, 1984

19. Kristjansen PE, Hansen $\mathrm{HH}$ : Brain metastases from small cell lung cancer treated with combination chemotherapy. Eur J Cancer Clin Oncol 24:545-549, 1988

20. Lee JS, Murphy WK, Glisson BS, et al: Primary chemotherapy of brain metastasis in smallcell lung cancer. J Clin Oncol 7:916-922, 1989

21. Humblet Y, Weynants P, Bosly A, et al: Carboplatin in association with etoposide and either Adriamycin or epirubicin for untreated small cell lung cancer: A dose escalation study of carboplatin-UCL Clinical Oncology Group. Med Oncol Tumor Pharmacother 6:207-212, 1989

22. Twelves CJ, Souhami RL, Harper PG, et al: The response of cerebral metastases in small cell lung cancer to systemic chemotherapy. Br J Cancer 61:147-150, 1990

23. Kristjansen PE, Soelberg Sorensen P, Skov Hansen M, et al: Prospective evaluation of the effect on initial brain metastases from small cell lung cancer of platinum-etoposide based induction chemotherapy followed by an alternating multidrug regimen. Ann Oncol 4:579583, 1993 
24. Tummarello D, Lippe P, Bracci R, et al: First line chemotherapy in patients with brain metastases from non-small and small cell lung cancer. Oncol Rep 5:897-900, 1998

25. Schuette W: Treatment of brain metastases from lung cancer: Chemotherapy. Lung Cancer 45:S253-S257, 2004 (suppl 2)

26. WHO: WHO Handbook for Reporting Results of Cancer Treatment. Geneva, Switzerland, WHO, 1979

27. Kleinbaum DG: Kaplan-Meier survival curves and the log-rank test in survival analysis: A self learning text (ed 2). New York, NY, Springer Verlag, 1997, pp 45-76

28. Schellinger PD, Meinck HM, Thron A: Diagnostic accuracy of MRI compared to CCT in patients with brain metastases. J Neurooncol 44:275-281, 1999

29. Blasberg RG, Groothuis DR:Chemotherapy of brain tumors: Physiological and pharmacokinetic considerations. Semin Oncol 13:70-82, 1986

30. Neuwelt EA, Barnett PA, Bigner DD, et al: Effects of adrenal cortical steroids and osmotic blood-brain barrier opening on methotrexate delivery to gliomas in the rodent: The factor of the blood-brain barrier. Proc Natl Acad Sci U S A 79:4420-4423, 1982 



\section{? \\ General discussion}

Clinical Practice: Brain metastases from Small Cell Lung Cancer. More questions than answers 


\section{General Discussion}

This chapter begins with a case vignette highlighting clinical problems. Evidence supporting various strategies is then presented, followed by a review of formal guidelines. The chapter ends with considerations and recommendations.

\section{Case}

In 2001 a 59-year-old woman with a 40 pack-year history of smoking was diagnosed with extensive disease Small Cell Lung Cancer (SCLC). Systemically the cancer had spread to the right adrenal gland. On routinely performed gadolinium enhanced magnetic resonance imaging (MRI) of the brain a single asymptomatic metastasis (diameter $8 \mathrm{~mm}$ ) was detected in the left parietal lobe.

She was initially treated with five cycles of combination chemotherapy (cyclofosfamide, doxorubicin and etoposide]. She had a complete systemic response based on computer tomography (CT) of the thorax and abdomen. However the brain metastasis (BM) was unaltered (stable disease). Eight months after the diagnosis of SCLC the patient suffered from de novo headaches and she developed a paresis of the right arm. A new MRI scan showed that the detected BM had progressed substantially to a diameter of approximately $30 \mathrm{~mm}$. Furthermore several new BM were detected. She then underwent whole brain radiotherapy (WBRT) (30 Gy in ten fractions). Three months after WBRT there was clinical and radiological progressive disease with an increase of edema in the left hemisphere. The patient died 13 months after the diagnosis of SCLC of cerebral herniation.

\section{The clinical problem}

SCLC accounts for approximately $13 \%$ of all lung cancers. ${ }^{1}$ It is a very aggressive rapidly growing tumor that disseminates early in the course of the disease. ${ }^{2}$ Dissemination to the central nervous system is a frequently encountered complication. ${ }^{3}$ The estimated prevalence of detected brain metastases (BM) when screening patients with SCLC immediate after diagnosis varies from $10 \%$ when computer tomography (CT) is used 
to $24 \%$ when MRI is used as diagnostic tool. The difference is predominantly caused by the detection of asymptomatic BM (chapter 4). At present, enhanced MRI is generally considered to be the imaging test of choice in patients suspected of BM. ${ }^{4,5}$ Increasingly, MRI of the brain is being recommended as part of the initial staging procedure in SCLC patients. ${ }^{6.8}$ As a consequence asymptomatic BM are detected more frequently.

There are numerous recent studies and reviews concerning treatment of symptomatic BM from solid tumors. However, asymptomatic BM are hardly ever mentioned, nor is their treatment discussed. ${ }^{4,6,9-13}$ Therefore in clinical practice, treatment decisions concerning asymptomatic BM are often made based on personal or local experience.

\section{The clinical problem can be summarized as follows:}

1) What is the optimal treatment for patients with asymptomatic synchronous BM from SCLC?

2) Should MRI of the brain be part of the initial standard staging procedure for asymptomatic SCLC patients?

\section{Biological model}

As stated above the estimated prevalence of detected BM in SCLC patients is $24 \%$ when MRI is used. Among patients without initial BM the approximate risk of developing symptomatic BM during the remainder of their lives is $50 \%$ for patients with extensive disease (at diagnosis of SCLC) and $28 \%$ for patients with limited disease (chapter 2 ). ${ }^{3}$ The widely accepted explanation for the high incidence of $\mathrm{BM}$, is the hypothesized presence of preexisting (sub-clinical) micro metastases in the brain at the time of diagnosis of SCLC..$^{14,15}$ The presumption is that the brain is a sanctuary for tumor cells, where metastases can grow beyond the reach of chemotherapy as a result of the blood brain barrier. ${ }^{16}$ The rationale of prophylactic cranial irradiation $(\mathrm{PCl})$ is based on this hypothesis: it is thought that irradiation prevents the development of clinically evident $B M{ }^{17}$ If this hypothesis is correct, then the word 'prophylactic' is actually a misnomer, since BM are already present but too small to be detected by imaging. 


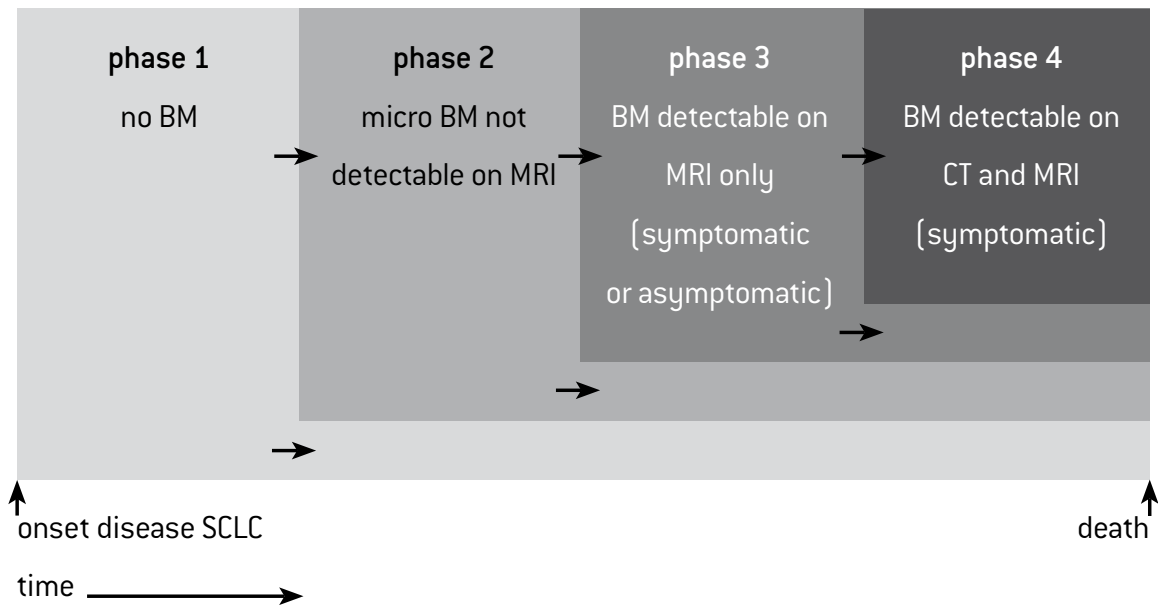

Figure 1 shows a simple model of the development of BM in SCLC patients. The model is based on earlier literature, combined with the findings as described in chapter 2 and 4 of this thesis. The diagnosis of SCLC can be made in four phases: phase 1 is early in the course of the disease, when dissemination to the brain has not yet occurred. It is generally thought that only few patients will be diagnosed with SCLC in this phase. Phase 2 represents the period in which sub-clinical micro BM are present, but they are not yet detectable with MRI or CT. In phase 3 BM are present which are large enough to be detected by MRI but not when a less sensitive technique is used. In this phase BM can be either clinically manifest or asymptomatic. In phase $4 \mathrm{BM}$ are clinically manifest and detectable with both MRI and CT.

Patients in whom the diagnosis of SCLC is made during phase 1 or 2 are eligible for $\mathrm{PCl}$. When CT is used to establish the diagnosis of $\mathrm{BM}$, phase 3 submerges in phase 2. Therefore, considering a patient eligible for $\mathrm{PCl}$ is partly dependent on the imaging technique used to detect BM. 


\section{Strategies and evidence}

\section{Treatment of synchronous BM from SCLC}

Until recently the standard of treatment for patients with BM from solid tumors in general, has been WBRT. However, surgical resection and stereotactic radiosurgery have emerged as an important treatment modality for patients with one to three $\mathrm{BM} .^{11,18 \text { - }}$ ${ }^{21}$ Because of the presumed presence of (sub-clinical) micro-metastases (figure 1) and their supposed tendency to be multiple, BM from SCLC are treated differently than those from other primary tumors. ${ }^{6,15}$ Therefore, in SCLC patients WBRT is considered to remain the standard palliative therapy regardless of the number of BM detected. ${ }^{6,11,13}$

Since SCLC is one of the most chemo sensitive tumors, systemic chemotherapy for the treatment of BM has been the subject of multiple papers. ${ }^{22.30}$ It has been suggested that synchronous BM from SCLC is adequately treated with systemic chemotherapy. ${ }^{10,31}$ However the existing evidence on this matter is inconclusive (chapter 5). In a recently performed analyses of 24 patients with asymptomatic BM treated up-front with systemic chemotherapy, we found a response rate of only $27 \%$ and we therefore concluded that systemic chemotherapy is not sufficient for the treatment of BM from SCLC (chapter 6). ${ }^{32}$

The treatment of clinical manifest BM from SCLC is unsatisfactory so far. It has been estimated that only about half of the patients achieve a useful palliation after WBRT. ${ }^{33}$ Considering this poor outcome, PCl was first proposed for all SCLC patients without detected BM. ${ }^{14} \mathrm{PCl}$ is now recommended for patients with limited disease SCLC who achieved complete response after initial therapy. In this group PCI reduces the risk of BM by approximately $50 \%$ and prolongs survival. ${ }^{17,34}$

\section{Imaging of the brain in SCLC patients}

Gadolinium enhanced MRI is the preferred imaging technique to establish the diagnosis of BM. ${ }^{5,6}$ Compared to contrast enhanced CT, MRI is considered 'superior', meaning that MRI is a more sensitive technique to detect BM. ${ }^{35-38} \mathrm{~A}$ retrospective analysis showed that the estimated prevalence of BM in SCLC increased from 10\% when CT was used to $24 \%$ in a period when MRI was used instead of CT to establish the diagnosis of BM. This difference was caused predominantly by the detection of asymptomatic BM (chapter 4) 


\section{Guidelines}

To see which strategies are currently followed for asymptomatic BM, we consulted two leading nation wide SCLC guidelines (from the United States and Great Britain respectively) and two Dutch regional SCLC guidelines. ${ }^{39.42}$ We furthermore explored two guidelines concerning BM in general. ${ }^{43,44}$ The guidelines we consulted on diagnosis and treatment of SCLC, disagree on the subject of screening for BM at initial diagnosis and the consequences it entails.

According to the most recent National Comprehensive Cancer Network practice guidelines (United States), MRI of the brain is recommended as part of the diagnostic workup in patients with SCLC, because early treatment of BM is presumed to result in less chronic neurologic morbidity. ${ }^{39}$ No references or considerations are presented to substantiate this statement. When asymptomatic BM are found through MRI, it is furthermore stated that radiotherapy may be administered after chemotherapy. There are no recommendations on how patient selection for such radiotherapy should take place. The optimal dose of radiotherapy and radiation technique (e.g. whole brain, SRS?) is also not discussed.

According to guidelines developed by the National Collaboration Centre for Acute Care in Great Britain (U.K.), imaging of the brain should be performed in symptomatic patients only. ${ }^{40}$ This recommendation is based on an analysis performed by Detterbeck et al, in which the reliability of neurological examinations for staging SCLC was studied. They concluded that CT or MRI of the brain is not worthwhile in asymptomatic patients. ${ }^{45}$

In The Netherlands two regional guidelines on SCLC are available. A nation wide guideline is currently under construction. In the guideline from the Comprehensive Cancer Centre Middle Netherlands it is stated that a CT scan of the brain should be performed, if extensive disease has not yet been demonstrated. The guideline does not elaborate on the treatment of asymptomatic BM. ${ }^{41}$ The guideline on SCLC from the Comprehensive Cancer Centre East Netherlands states that imaging of the brain is not useful as part of the initial staging procedure, even though the authors acknowledge that small BM will be missed. ${ }^{42}$

The two studied guidelines, on BM from solid tumors in general, disagree on the optimal treatment for BM from SCLC. According to the Dutch guidelines on BM, synchronous 
BM from SCLC should be treated with first-line systemic chemotherapy. ${ }^{43}$ In the practice guideline on central nervous system cancer from the National Comprehensive Cancer Network, systemic chemotherapy is not mentioned as a treatment option for BM from SCLC. It is stated that patients should be treated with WBRT, regardless of the number of lesions. ${ }^{44}$ In both guidelines diagnosis and treatment of asymptomatic BM is not addressed.

\section{Considerations and recommendations}

From the overview of existing guidelines it becomes apparent that there are many uncertainties and disagreements about the treatment of patients with asymptomatic BM from SCLC. This also illustrates that guidelines should always be interpreted with caution. The answer to the question whether MRI of the brain should be part of the initial staging procedure in asymptomatic SCLC patients, is dependent on the treatment consequences it entails. Two lines of thoughts can be discerned:

In the PCl trials, CT was used for the exclusion of the presence of BM. ${ }^{17}$ However a proportion of the patients who underwent $\mathrm{PCl}$, would have been diagnosed with asymptomatic BM if MRI had been used. Therefore, it seems consistent to advise PCl for patients with asymptomatic BM on MRI. In this case 'prophylactic' stands for prevention of BM to become symptomatic and including MRI of the brain in the staging procedure would be appropriate. On the other hand, it has not been shown that radiotherapy actually prevents or postpones the development of clinical symptoms and signs from BM. Therefore it is also justifiable to only treat patients with radiotherapy when BM become clinically manifest. Screening for asymptomatic BM would then be redundant.

\section{Back to the case:}

This patient underwent MRI of the brain, as part of the standard procedure of initial staging of SCLC patients in our hospital. The single BM was asymptomatic and accordingly to the local protocol for SCLC patients, first-line systemic chemotherapy was given. The patient remained asymptomatic for eight months. After clinical symptoms and signs appeared a new MRI showed multiple lesions. In this stage WBRT did not achieve adequate palliation. 
Had this patient been diagnosed in the eighties, she would have undergone CT of the brain instead of MRI. It is very likely that the single lesion would not have been detected and she would have undergone $\mathrm{PCl}$ shortly after the chemotherapy.

If a similar case would occur now, we would be inclined to irradiate, simply because we detected a metastases and we have learned that asymptomatic BM do not respond to systemic chemotherapy in most cases (chapter 6). However, considering the lack of evidence and consensus on the treatment of asymptomatic $\mathrm{BM}$, the question still remains whether detection of these asymptomatic BM is really useful.

\section{For the future:}

With the development of increasingly more sensitive diagnostic techniques clinicians in oncology are confronted with the detection of ever smaller and therefore also larger number of metastases. The obvious next step would be to investigate what the optimal treatment for these newly detected metastases is.

In the case of SCLC, the change from CT to MRI of the brain has led to the detection of asymptomatic BM in about $10 \%$ of the patients. For now it is unknown what the best treatment for this patient group is. In our opinion, a randomized trial should be undertaken to investigate the effectiveness of 'prophylactic' cranial irradiation (total dose 30 Gy, administered as either $3 \mathrm{~Gy} 4$ times a week or 2 Gy given 5 times a week] when MRI is used to establish the diagnosis of asymptomatic BM. In this trial patients should undergo both MRI and CT of the brain. Patients who are in CR after initial chemotherapy and have BM detected with MRI but not through CT should be randomized to receiving cranial irradiation or not. The results of a suchlike trial would constitute an important contribution to the discussion about the optimal treatment of asymptomatic BM. 


\section{References}

1. Govindan R, Page N, Morgensztern D, et al: Changing epidemiology of small-cell lung cancer in the United States over the last 30 years: analysis of the surveillance, epidemiologic, and end results database. J Clin Oncol 24:4539-44, 2006

2. Elias AD: Small cell lung cancer: state-of-the-art therapy in 1996. Chest 112:251S-258S, 1997

3. Seute T, Leffers P, ten Velde GP, et al: Neurologic disorders in 432 consecutive patients with small cell lung carcinoma. Cancer 100:801-6, 2004

4. Davey P: Brain metastases: treatment options to improve outcomes. CNS Drugs 16:325-38, 2002

5. Kaal EC, Taphoorn MJ, Vecht CJ: Symptomatic management and imaging of brain metastases. J Neurooncol 75:15-20, 2005

6. Schwer AL, Gaspar LE: Update in the treatment of brain metastases from lung cancer. Clin Lung Cancer 8:180-6, 2006

7. Wagner $\mathrm{H}, \mathrm{Jr}$.: Treatment of brain metastases in patients with small-cell lung cancer: lessons from treatment of other tumors. Clin Lung Cancer 2:29-40, 2000

8. Stupp R, Monnerat C, Turrisi AT, 3rd, et al: Small cell lung cancer: state of the art and future perspectives. Lung Cancer 45:105-17, 2004

9. Gaspar LE: Brain metastases in lung cancer. Expert Review of Anticancer Therapy 4: 259-270, 2004

10. Grossi F, Scolaro T, Tixi L, et al: The role of systemic chemotherapy in the treatment of brain metastases from small-cell lung cancer. Crit Rev Oncol Hematol 37:61-?., 2001

11. Kaal EC, Niel CG, Vecht CJ: Therapeutic management of brain metastasis. Lancet Neurol 4: 289-98, 2005

12. Langer CJ, Mehta MP: Current management of brain metastases, with a focus on systemic options. J Clin Oncol 23:6207-19, 2005

13. Soffietti R, Costanza A, Laguzzi E, et al: Radiotherapy and chemotherapy of brain metastases. J Neurooncol 75:31-42, 2005 
14. Hansen HH: Should initial treatment of small cell carcinoma include systemic chemotherapy and brain irradiation? Cancer Chemother Rep 3 4:239-41, 1973

15. Mehta MP: Models support prophylactic cranial irradiation. J Clin Oncol 24:3524-6, 2006

16. Van de Pol M, ten Velde GP, Wilmink JT, et al: Efficacy and safety of prophylactic cranial irradiation in patients with small cell lung cancer. J Neurooncol 35:153-60., 1997

17. Auperin A, Arriagada R, Pignon JP, et al: Prophylactic cranial irradiation for patients with small-cell lung cancer in complete remission. Prophylactic Cranial Irradiation Overview Collaborative Group. N Engl J Med 341:476-84, 1999

18. Andrews DW, Scott CB, Sperduto PW, et al: Whole brain radiation therapy with or without stereotactic radiosurgery boost for patients with one to three brain metastases: phase III results of the RTOG 9508 randomised trial. Lancet 363:1665-72, 2004

19. Soffietti R, Cornu P, Delattre JY, et al: EFNS Guidelines on diagnosis and treatment of brain metastases: report of an EFNS Task Force. Eur J Neurol 13:674-81, 2006

20. Tsao MN, Lloyd NS, Wong RK: Clinical practice guideline on the optimal radiotherapeutic management of brain metastases. BMC Cancer 5:34, 2005

21. Lim LC, Rosenthal MA, Maartens N, et al: Management of brain metastases. Intern Med J 34:270-8, 2004

22. Conte PF, Giaccone G, Musella R, et al: Combination chemotherapy for metastatic brain tumors. Tumori 67:559-62, 1981

23. Kantarjian H, Farha PA, Spitzer G, et al: Systemic combination chemotherapy as primary treatment of brain metastasis from lung cancer. South Med J 77:426-30, 1984

24. Kristjansen PE, Hansen $\mathrm{HH}$ : Brain metastases from small cell lung cancer treated with combination chemotherapy. Eur J Cancer Clin Oncol 24:545-9., 1988

25. Humblet $\mathrm{Y}$, Weynants $\mathrm{P}$, Bosly A, et al: Carboplatin in association with etoposide and either adriamycin or epirubicin for untreated small cell lung cancer: a dose escalation study of carboplatin. UCL Clinical Oncology Group. Med Oncol Tumor Pharmacother 6:207-12, 1989

26. Lee JS, Murphy WK, Glisson BS, et al: Primary chemotherapy of brain metastasis in small-cell lung cancer. J Clin Oncol 7:916-22, 1989 
27. Kearns F, Grogan L, Harford P, et al: Resolution of small cell lung cancer intracranial metastases with standard dose chemotherapy. Ir J Med Sci 158:308-9, 1989

28. Kristjansen PE, Soelberg Sorensen P, Skov Hansen M, et al: Prospective evaluation of the effect on initial brain metastases from small cell lung cancer of platinum-etoposide based induction chemotherapy followed by an alternating multidrug regimen. Ann Oncol 4: 579-83., 1993

29. Malacarne P, Santini A, Maestri A: Response of brain metastases from lung cancer to systemic chemotherapy with carboplatin and etoposide. Oncology 53:210-3, 1996

30. Tummarello D, Lippe P, Bracci R, et al: First line chemotherapy in patients with brain metastases from non- small and small cell lung cancer. Oncol Rep 5:897-900., 1998

31. Kristensen CA, Kristjansen PE, Hansen HH: Systemic chemotherapy of brain metastases from small-cell lung cancer: a review. J Clin Oncol 10:1498-502., 1992

32. Seute T, Leffers P, Wilmink JT, et al: Response of asymptomatic brain metastases from small-cell lung cancer to systemic first-line chemotherapy. J Clin Oncol 24:2079-83, 2006

33. Carmichael J, Crane JM, Bunn PA, et al: Results of therapeutic cranial irradiation in small cell lung cancer. Int J Radiat Oncol Biol Phys 14:455-9, 1988

34. Meert AP, Paesmans M, Berghmans T, et al: Prophylactic cranial irradiation in small cell lung cancer: a systematic review of the literature with meta-analysis. BMC Cancer 1:5, 2001

35. Sze G, Milano E, Johnson C, et al: Detection of brain metastases: comparison of contrastenhanced MR with unenhanced MR and enhanced CT. AJNR Am J Neuroradiol 11:785-91, 1990

36. Schellinger PD, Meinck HM, Thron A: Diagnostic accuracy of MRI compared to CCT in patients with brain metastases. J Neurooncol 44:275-81, 1999

37. Yokoi K, Kamiya N, Matsuguma $\mathrm{H}$, et al: Detection of brain metastasis in potentially operable non-small cell lung cancer: a comparison of CT and MRI. Chest 115:714-9, 1999

38. Suzuki K, Yamamoto M, Hasegawa Y, et al: Magnetic resonance imaging and computed tomography in the diagnoses of brain metastases of lung cancer. Lung Cancer 46:357-60, 2004 
39. Ettinger D, Johnson B: Update: NCCN small cell and non-small cell lung cancer Clinical Practice Guidelines. J Natl Compr Canc Netw 3 Suppl 1:S17-21, 2005

40. National Collaborating Centre for Acute Care: Diagnosis and treatment of lung cancer. London,. Available from www.rcseng.ac.uk, 2005

41. Comprehensive Cancer Centre Middle Netherlands: kleincellig bronchuscarcinoom, versie $1.1,2002$

42. Comprehensive Cancer Centre East Netherlands: Richtlijn kleincellig bronchuscarcinoom, versie 2.0, 2003

43. Association of Comprehensive Cancer Centres : Dutch guideline brain metastases (Landelijke richtlijn hersenmetastasen), 2004

44. National Comprehensive Cancer Network: Clinical practice guidelines Central nervous system cancers, version 2.0, 2006

45. Detterbeck FC JD, Molina PL: Extrathoracic staging, in Detterbeck FC RM, Socinski MA, Rosenman JG (ed): Diagnosis and treatment of lung cancer: An evidence-based guide for the practicing clinician. Philadelphia, W.B. Saunders Company, 2001, pp 94-110 

Summary and conclusions

Samenvatting

Dankwoord

Curriculum vitae 


\section{Summary and conclusions}

Small Cell Lung Cancer (SCLC) is frequently complicated by neurologic disorders. Especially the metastatic neurologic complications contribute heavily to morbidity and mortality in SCLC patients.

In this thesis several studies were presented intending to improve our understanding of neurologic disorders in SCLC patients. One of the main goals of this thesis was to provide a more accurate estimation of the frequencies of neurologic disorders in general and brain metastases (BM) in particular (chapter 2,3 and 4). Another major aim was to add relevant information to the debate concerning the treatment of synchronous BM from SCLC (chapter 5,6 and ?).

In chapter 2 we described the frequency and survival of neurologic disorders in 432 consecutive SCLC patients. Neurologic disorders were actively searched for through regular patient examinations by an experienced neurologist. Also imaging of the brain was performed routinely. More than half of the patients (56\%) were diagnosed with a neurologic disorder at some point during their disease. As expected, BM were diagnosed most frequently. In $18 \%$ of the patients BM were detected at diagnosis of SCLC. The life-time incidence of BM was $50 \%$ for patients with extensive disease and $28 \%$ for patients with limited disease. Contrary to earlier reports in the literature, we found that BM had a negative effect on the survival of SCLC patients. BM were found to be the direct cause of dead in nearly half of the patients with BM.

In chapter 3 we presented several aspects on leptomeningeal metastases (LMM) in SCLC patients. At the time of diagnosis of SCLC 2\% of the 458 patients included in this study, were found to have LMM. Another $10 \%$ were diagnosed with LMM during follow-up. We found that patients with LMM located around the spinal cord appeared to survive longer than patients with cranial LMM. We furthermore found that $15 \%$ of the patients with BM located in the posterior fossa developed LMM, whereas only $10 \%$ of patients with cerebral BM did. From this we concluded that patients with BM in the posterior fossa may be at higher risk of developing LMM compared to patients with cerebral BM. 
In chapter 4 we focused on the effect of changing from computer tomography (CT) to magnetic resonance imaging (MRI) on the prevalence of BM in patients with newly diagnosed SCLC. Brain imaging was routinely performed in the 481 included patients. At the start of $1991 \mathrm{MRI}$ replaced CT. We found that the estimated prevalence of BM increased from $10 \%$ to $24 \%$ in the period when MRI was used instead of CT. This difference was predominantly caused by the detection of asymptomatic BM (11\%) through MRI. In both periods patients labeled as single BM survived longer than those labeled as multiple BM. For patients labeled as single BM as well as patients labeled as multiple BM, survival was longer in the MRI era than the CT era. We showed that this seemingly increased survival could be attributed to the "Will Rogers phenomenon". We furthermore found that the proportion of patients who were considered eligible for prophylactic cranial irradiation was lower when MRI is used.

In chapter 5 we described a systematic review which aimed to assess the effect of first-line chemotherapy on synchronous BM in SCLC patients. Eleven observational studies or case reports reporting on this subject were found and discussed. No reports of randomized or not randomized clinical trials were retrieved. We concluded that there is insufficient evidence about the effectiveness of first-line chemotherapy for the treatment of synchronous BM from SCLC.

In chapter 6 we investigated the radiologic response of synchronous asymptomatic BM to first-line systemic chemotherapy in 24 SCLC patients. In six (27\%) patients the asymptomatic BM responded, whereas in 16 (73\%) patients a systemic response was found. From these results we concluded that systemic chemotherapy is not sufficient for the treatment of synchronous asymptomatic BM from SCLC.

In chapter 7 we presented a clinical case concerning a SCLC patient with synchronous asymptomatic BM. Proceeding from this case we discussed the treatment of asymptomatic BM and the usefulness of including MRI of the brain in the initial staging procedure. We explored relevant guidelines on these subjects and also incorporated results and conclusions described in former chapters of this thesis. The answer to the question whether MRI of the brain should be part of the initial staging procedure in asymptomatic 
SCLC patients is dependent on the treatment consequences it entails. We found that there are many uncertainties and disagreements about the treatment of SCLC patients with asymptomatic BM. We therefore concluded that a randomized trial should be undertaken to investigate the effectiveness of 'prophylactic' cranial irradiation for asymptomatic BM. 


\section{Samenvatting}

Bij patiënten met kleincellig longcarcinoom (Small Cell Lung Cancer = SCLC) komen neurologische complicaties vaak voor. Vooral het metastaseren van de ziekte naar het zenuwstelsel verhoogt de mortaliteit en morbiditeit van SCLC patiënten aanzienlijk.

In dit proefschrift werden een aantal studies beschreven, met de intentie het begrip en de kennis over neurologische aandoeningen bij SCLC te verbeteren. Eén van de belangrijkste doelstellingen van dit proefschrift was om bij SCLC patiënten een adequatere schatting te maken van het aantal neurologische complicaties in het algemeen en hersenmetastasen (HM) in het bijzonder (hoofdstuk 2,3 en 4). Een ander belangrijk doel betrof het leveren van een relevante bijdrage aan het debat betreffende de behandeling van synchrone HM van SCLC (hoofdstuk 5,6 en ?).

In hoofdstuk 2 beschreven we de frequenties van neurologische complicaties en overlevingsduur bij 432 opeenvolgende SCLC patiënten. Middels geregeld klinisch neurologisch onderzoek door een ervaren neuroloog werd actief gezocht naar deze neurologische complicaties. Tevens werd routinematig beeldvorming van de hersenen verricht. Bij meer dan de helft van de patiënten (56\%) werd tijdens het ziektebeloop een neurologische aandoening gediagnosticeerd. Zoals verwacht werden HM het meest frequent gediagnosticeerd. Bij 18\% van de patiënten werden HM gevonden bij het stellen van de diagnose SCLC. De incidentie van HM gedurende de rest van het leven was $50 \%$ voor patiënten met uitgebreide ziekte (extensive disease) en $28 \%$ voor patiënten met beperkte ziekte (limited disease). In tegenstelling tot hetgeen vermeld werd in eerdere publicaties, vonden wij dat HM een negatief effect hadden op de overleving van SCLC patiënten. In bijna de helft van de patiënten bleken HM de directe doodsoorzaak.

In hoofdstuk 3 beschreven wij verscheidene aspecten van leptomeningeale metastasen (LMM) bij SCLC patiënten. Bij diagnose van de ziekte SCLC, werden LMM gevonden bij 2\% van de 458 geïncludeerde patiënten. Gedurende het ziektebeloop werd bij nog eens $10 \%$ van de patiënten de diagnose LMM gesteld. Patiënten met spinaal gelokaliseerde LMM leken langer te overleven dan patiënten met craniaal gelokaliseerde LMM. 
Tevens vonden wij dat 15\% van de patiënten met HM in de achterste schedelgroeve LMM ontwikkelden, vergeleken met slechts $10 \%$ van de patiënten met supratentoriële HM. Dit leidde tot de conclusie dat patiënten met HM in de achterste schedelgroeve wellicht een groter risico hebben op het krijgen van LMM dan patiënten met cerebrale HM.

In hoofdstuk 4 werd beschreven hoe de prevalentie van HM in patiënten met recent gediagnosticeerd SCLC, werd beïnvloed door de vervanging van computer tomography $(\mathrm{CT})$ door magnetische resonance imaging (MRI). Beeldvorming van de hersenen werd routinematig verricht in 481 geïncludeerde patiënten. In 1991 werd CT vervangen door MRI. Wij vonden dat in de periode waarin MRI werd gebruikt in plaats van CT, de geschatte prevalentie van HM steeg van $10 \%$ naar $24 \%$. Dit verschil werd voornamelijk veroorzaakt door de detectie van asymptomatische HM [11\%] middels MRI. In beide perioden was de overleving langer voor patiënten gediagnosticeerd met enkelvoudige HM, vergeleken met patiënten gediagnosticeerd met multipele HM. We toonden aan dat deze schijnbare verbetering van de overleving kan worden toegeschreven aan het "Will Rogers fenomeen". Verder vonden wij dat verhoudingsgewijs minder patiënten in aanmerking komen voor profylactische schedel bestraling wanneer MRI wordt gebruikt in plaats van CT.

In hoofdstuk 5 werd een systematische review beschreven, waarin het effect van eerstelijns chemotherapie op synchrone HM bij SCLC patiënten werd onderzocht. Er werden elf observationele studies of casus beschrijvingen gevonden en bediscussieerd. Klinische trials, al dan niet gerandomiseerd, werden niet gevonden. Wij concludeerden dat er onvoldoende bewijs is over de effectiviteit van eerstelijns chemotherapie op HM van SCLC.

In hoofdstuk 6 werd de radiologische respons van synchrone asymptomatische HM op eerstelijns chemotherapie onderzocht in 24 SCLC patiënten. Bij slechts zes patiënten (27\%) was er een respons van de asymptomatische HM, terwijl er bij 16 patiënten (73\%) een systemische respons werd vastgesteld. Wij concludeerden op basis van deze resultaten dat eerstelijns systemische chemotherapie niet toereikend als behandeling van asymptomatische synchrone HM van SCLC.

In hoofdstuk $?$ beschreven wij een klinische casus betreffende een SCLC patiënte met synchrone asymptomatische HM. Uitgaande van deze casus bediscussieerden wij de 
behandeling van asymptomatische $\mathrm{HM}$ en het nut van het includeren van MRI hersenen in het initiële stadiëringsonderzoek. Wij bestudeerden relevante richtlijnen over deze onderwerpen en betrokken daarnaast resultaten en conclusies uit eerdere hoofdstukken van dit proefschrift. Het antwoord op de vraag of MRI hersenen onderdeel moet uitmaken van initieel stadiëringsonderzoek bij asymptomatische patiënten SCLC, hangt af van de eventuele behandelconsequenties. Wij vonden dat er veel onduidelijkheden en tevens onenigheden bestaan omtrent de behandeling van SCLC patiënten met asymptomatische HM. Mede daarom concludeerden wij dat een gerandomiseerde trial zou moeten worden verricht om de effectiviteit van 'profylactische' schedel bestraling op asymptomatische HM vast te stellen. 


\section{Dankwoord}

In de afgelopen zeven jaar is dit proefschrift tot stand gekomen. Bij de start van het onderzoek in 2000 werd de verwachte promotiedatum veel eerder geschat. Echter bij het zoeken naar de juiste balans tussen goede patiëntenzorg en wetenschap, sloeg deze bij mij veelal door naar het eerste. Gelukkig heb ik mij in alle jaren gesteund geweten door een klein maar zeer vastberaden begeleidingsteam en een warm nest van naasten, collega's, vrienden en familie. Het is fijn de gelegenheid te krijgen een aantal van deze mensen persoonlijk te bedanken:

Dr. A. Twijnstra, beste Albert, je bent als co-promotor en initiator van dit onderzoek tijdens de hele periode een groot motivator geweest. Jouw kracht lag in het uitzetten van de grote lijnen en het behouden van de juiste koers. Ook buiten dit onderzoek delen we de interesse voor de oncologische patiënten binnen de neurologie. Onder jouw supervisie heb ik de kans gekregen om me tijdens de opleiding hierop toe te leggen. Veel dank voor de samenwerking en begeleiding.

Drs. Ir. P. Leffers, beste Pieter, jouw rol als epidemioloog, medeschrijver, coach en begeleider was onmisbaar. Met groot geduld heb je me ingewijd in de wereld van epidemiologie en statistiek. Manuscripten werden na jouw inbreng plots duidelijk en leesbaar. Je hebt me geleerd in het kader van dit onderzoek, maar ook in het algemeen kritisch naar wetenschap te kijken en de juiste brug te slaan naar de kliniek. Onze intensieve samenwerking heeft grote invloed gehad op mij als (beginnend) wetenschapper en heeft me daarnaast gemaakt tot een beter clinicus. Ben er trots op dat je straks naast me staat.

Dr. G.P.M. ten Velde, beste Guul, dank voor je waardevolle bijdragen aan de verschillende artikelen en manuscripten, het meedenken over de grote lijnen van het onderzoek en hulp bij de jarenlange verzameling van data van patiënten. 
Prof. dr. M. Limburg en prof. dr. M.H. Prins, beste Martien en Martin, ik ben blij dat mijn promotie plaatsvindt onder de gezamenlijke vlag van de vakgroepen neurologie en epidemiologie in Maastricht, alwaar ik een fantastische tijd heb gehad. Dank voor de geboden mogelijkheden.

Prof. dr. J. Troost, beste Jaap, dank voor het in mij gestelde vertrouwen. Als opleider wist je me met weinig woorden altijd te overtuigen van mijn eigen kunnen.

Lieve PMO-ers, geneeskunde makkers vanaf de eerste dag van onze studie in 1993. Wat fantastisch dat de vriendschap er nog altijd is! Lieve Monique, van meerdere belangrijke momenten in mijn leven ben je letterlijk en figuurlijk getuige geweest, het geeft een heerlijk vertrouwd gevoel dat je ook straks naast me staat.

Collega neurologen, klinisch neurofysiologen en (oud) arts-assistenten van het AzM, het afscheid van het door mij zo geliefde Maastricht deed een beetje pijn. Dank voor alle vriendschap, steun en gezelligheid. De vrijdagavond borrels (nogal eens diep in de nacht eindigend met de 'neuro-yell'], de etentjes (al dan niet met Heimlichmanoeuvre) en alle andere momenten, maken dat ik terug kijk op een mooie tijd.

Collega neurologen, arts-assistenten, en collega's betrokken bij de neurooncologie van het UMCU, dank voor het hartelijke welkom in het Utrechtse. De prettige werksfeer, de oprechte belangstelling en waardering die mij ten deel zijn gevallen hebben het bovenbeschreven afscheid uit 'het Zuiden' verzacht en gemaakt dat ik me direct thuis voelde. Ik zie uit naar de verdere samenwerking in de toekomst.

Prof. dr. J.H.J. Wokke, beste John, de ondersteuning en geboden mogelijkheden in de afrondingsfase van dit proefschrift waren zeer kostbaar, mijn dank hiervoor. 
Lieve vrienden en familie, die ik minder aandacht heb kunnen geven dan ik zou willen, omdat er altijd nog wel iets moest gebeuren; het is echt af! Dank voor de niet aflatende aanmoedigingen en belangstelling.

Rob Köppen, Rob(bie), zonder jou was dit boekje er niet geweest. Je liefde, steun en vertrouwen vormden het fundament waarop zoveel werd gebouwd. Mijn intense dank voor alles.

Er is één iemand die nog blijer is dan ik, dat het af is; mijn lieve moeder. Mammie, dank voor alles wat je me hebt meegegeven in al die jaren, je bent onmetelijk verantwoordelijk voor wie ik ben geworden en wat ik heb kunnen bereiken.

Rob Rundervoort, Mijn Liefste, we kenden elkaar al lang, maar vonden elkaar pas veel later. Ondanks de hectiek van de afgelopen tijden heb je me steeds weer de rust en het zelfvertrouwen gegeven, waardoor dit boekje er nu dan echt ligt. Dank voor het lezen van manuscripten, het herhaaldelijk herstellen van gecrashte of op mysterieuze manier verdwenen documenten (terwijl ik echt niets had gedaan!) en stressmanagement in de laatste fase. Je bent het allermooiste dat ik ken. 


\section{Curriculum Vitae}

Tatjana Seute werd geboren op 15 november 1971 te Heerlen. In 1990 behaalde zij het HAVO diploma aan het Sint-Janscollege te Hoensbroek. Het VWO diploma behaalde zij twee jaar later aan het Serviam College te Sittard. Mede door uitloting voor de studie Geneeskunde, startte zij hierna de opleiding M.E.A.O. (commerciële richting) aan het Stercollege te Maastricht alwaar in 1993 het diploma werd behaald evenals het deelcertificaat Natuurkunde (VWO). Aansluitend begon zij alsnog met de studie Geneeskunde aan de Universiteit Maastricht. Gedurende de hele studie stond het specialisme Neurologie centraal in haarbelangstelling. Een uitzondering hierop vormde de in 1997 gevolgde wetenschappelijke stage aan de University of Toronto (department of Physiology \& Obstetrics] in het laboratorium van prof. J. Chalis, alwaar onderzoek werd gedaan naar pre-terme bevallingen. Het diploma basisarts ontving zij op 30 augustus 1999. Van september 1999 tot februari 2000 was zij werkzaam als arts-assistent Neurologie (agnio) in het Maaslandziekenhuis te Sittard. Van hieruit werd een doorstart gemaakt naar het Academisch Ziekenhuis Maastricht, waar zij in augustus 2000 begon met de opleiding tot neuroloog (destijds opleider prof.dr. J. Troost). Rond die tijd werd tevens, onder begeleiding van dr. A. Twijnstra en drs.ir. P.Leffers, een begin gemaakt met het onderzoek hetgeen uiteindelijk heeft geresulteerd in dit proefschrift. Sinds april 2006 is zij werkzaam als neuroloog met aandachtsgebied neuro-oncologie, in het Universitair Medisch Centrum Utrecht. 